\title{
Diabetic lung disease: fact or fiction?
}

\author{
Saeed Kolahian ${ }^{1,2,3} \cdot$ Veronika Leiss $^{1} \cdot$ Bernd Nürnberg ${ }^{1,2}$ \\ Published online: 21 October 2019 \\ (C) Springer Science+Business Media, LLC, part of Springer Nature 2019
}

\begin{abstract}
Diabetes mellitus is a chronic, progressive, incompletely understood metabolic disorder whose prevalence has been increasing steadily worldwide. Even though little attention has been paid to lung disorders in the context of diabetes, its prevalence has recently been challenged by newer studies of disease development. In this review, we summarize and discuss the role of diabetes mellitus involved in the progression of pulmonary diseases, with the main focus on pulmonary fibrosis, which represents a chronic and progressive disease with high mortality and limited therapeutic options.
\end{abstract}

Keywords Diabetes mellitus $\cdot$ Pulmonary disease $\cdot$ Lung $\cdot$ Fibrosis

\section{Abbreviations}

ALI acute lung injury

ARDS acute respiratory distress syndrome

AGE advanced glycation end product

ASMs airway smooth muscle cells

ASL airway surface liquid

CO carbon monoxide

COPD chronic obstructive pulmonary disease

CTGF connective tissue growth factor

CFRD cystic fibrosis-related diabetes

DM diabetes mellitus

EMT epithelial-mesenchymal transition

ECM extracellular matrix

FEV1 forced expiratory volume in one second

IPF idiopathic pulmonary fibrosis

IL interleukin
MAPK mitogen-activated protein kinase

NOX NADPH oxidase

NFKB nuclear factor kappa-light-chain-enhancer

of activated B-cells

PI3K phosphoinositide-3-kinases

RNS reactive nitrogen species

ROS reactive oxygen species

Rock Rho-associated protein kinase

STAT3 signal transducer and activator of transcription 3

STZ streptozotocin

Th1 T helper type 1 cell

Th2 Thelper type 2 cell

TGF $\beta$ transforming growth factor $\beta$

T1DM type 1 diabetes mellitus

T2DM type 2 diabetes mellitus

\section{Introduction}

Saeed Kolahian

Saeed.Kolahian@med.uni-tuebingen.de

1 Department of Pharmacology and Experimental Therapy, Institute of Experimental and Clinical Pharmacology and Toxicology, and Interfaculty Center of Pharmacogenomics and Drug Research (ICePhA), Eberhard Karls University Hospitals and Clinics, Tübingen, Germany

2 Department of Toxicology, Institute of Experimental and Clinical Pharmacology and Toxicology, Eberhard Karls University Hospitals and Clinics, Tübingen, Germany

3 Department of Pharmacogenomics, University of Tübingen, Wilhelmstrasse. 56, D-72074 Tübingen, Germany
Diabetes mellitus (DM) along with its associated complications is a global health problem that has expanded over the past several decades [1]. According to the current information from the World Health Organization, 8.5\% (442 million persons) of the worldwide adult population had DM in 2014, which nearly doubled since 1980 (4.7\%) [2]. The International Diabetes Federation has estimated that the number of diabetic patients worldwide will rise to 592 million in 2035 [3]. Large population-based studies reported 3.7 million deaths due to DM and its associated complications in 2012 [2]. DM is a heterogeneous metabolic disorder characterized by the presence of hyperglycemia due to impaired insulin secretion, defective insulin action or both [4]. The disease 
can be classified into the following general categories: 1. type 1 diabetes mellitus (T1DM) (due to autoimmune pancreatic $\beta$ cell loss, leading to absolute insulin deficiency); 2 . type 2 diabetes mellitus (T2DM) (due to dysfunctional pancreatic $\beta$-cells and insulin resistance, leading to progressively impaired glucose regulation); 3. gestational DM (a condition diagnosed in the second or third trimester of pregnancy that was not clearly overt diabetes prior to gestation); 4. specific types of DM due to other causes, e.g., monogenic diabetes syndromes, diseases of the exocrine pancreas, and drug- or chemical-induced diabetes $[4,5]$. T1DM, also known as autoimmune diabetes, is a chronic disease that is not preventable and that has no available cure. Affected patients depend on lifelong insulin substitution due to pancreatic $\beta$-cell destruction by islet-targeting autoantibodies that results in absolute insulin deficiency. Usually, the symptomatic onset is during childhood or adolescence however, symptoms can sometimes develop much later (latent autoimmune diabetes of adults). The underlying pathophysiology is characterized by the persistent presence of two or more autoantibodies, and the progression depends on the age at first antibody detection (the younger the individual, the faster the progression), the number of antibodies (the more antibodies present, the faster the progression), antibody specificity (the more specific the antibody, the faster the progression), and antibody titer (the higher the titer, the faster the progression). Genetic linkage studies have identified polymorphic variations in the class II genes encoding HLA-DR and HLA-DQ as well as one or more additional genes within the HLA region that increase the genetic risk for T1DM [6]. The progression of the disease can be divided into three stages depending on the absence or presence of hyperglycemia and hyperglycemia-associated symptoms (such as polyuria, polydipsia, recurrent infections, sudden weight loss and diabetic ketoacidosis) [4]. T2DM, which is much more common than T1DM (accounting for $90 \%$ of all DM disorders worldwide), is primarily a problem of progressively impaired glucose regulation due to a combination of dysfunctional pancreatic $\beta$-cells and insulin resistance. T2DM patients comprise a heterogeneous group. In most patients, alimentary obesity and physical inactivity significantly contribute to the increasing prevalence of T2DM diagnoses; however, some patients have a normal body weight but develop T2DM over time. Various pharmacologic approaches, all of which control glycemia, can be considered for patients with T2DM. First-line therapy is based on metformin unless specific contraindications such as renal impairment occurs. The molecular mechanism of metformin is incompletely understood but involves inhibiting the mitochondrial respiratory chain (complex I) and activating 5'-AMP-activated protein kinase, which mainly affects lipid metabolism [7, 8]. All other glucose-lowering therapies such as sulfonylureas, glucagonlike-peptide-1 analogues, dipeptidyl peptidase IV inhibitors, sodium-glucose-transporter-2-inhibitors and peroxisome proliferator-activated receptor gamma agonists are considered second-line agents for addition to metformin if glycemic targets are not reached. Most of these drugs directly or indirectly target organs involved in T2DM development, including the pancreas ( $\beta$-cells and $\alpha$-cells), liver, skeletal muscle, kidneys, brain, small intestine, and adipose tissue. The common problem of untreated diabetes subtypes is an increasing risk of long-term complications. These long-term complications are subdivided into neurological, microvascular and macrovascular complications. Microvascular complications manifest as nephropathy and retinopathy leading to kidney failure and blindness. Macrovascular complications include not only coronary heart disease but also cerebrovascular disease and peripheral artery disease $[4,5]$, that the latter even to the point of amputation. These complications are the main focus of ongoing studies, and the overall goal of the available therapies is to reduce or avoid these health-threatening problems. In addition to these complications, different pulmonary abnormalities, such as pronounced decrements in lung function, have been reported in patients with DM [9]. In this context, increasing attention has been given to recognizing pulmonary dysfunction and the underlying etiology as a complication of DM [9]. Our review focuses on the effects of DM on the pulmonary system with an overview of the association between DM and lung disorders, mainly pulmonary fibrosis, and suggestions for future research on the lung as a target organ for DM.

\section{Pathophysiology of lung dysfunction in patients with DM}

The pathophysiology of pulmonary symptoms in DM (Fig. 1) is complex and multifactorial and not completely understood. The currently known underlying mechanisms for lung dysfunction in patients with DM include hyperglycemia [10] (Fig. 2), hyperinsulinemia [11] (Fig. 3), autonomic neuropathy [12], oxidative stress [13], micro/macroangiopathy of alveolar capillaries and pulmonary arterioles [14, 15], glycosylation of tissue proteins $[16,17]$, collagen and elastin changes $[18,19]$, alteration of connective tissue [20, 21], surfactant dysfunction $[22,23]$ and malfunction of respiratory muscles $[24,25]$.

In 1976, Schuyler et al. for the first time reported a reduction in lung elastic recoil in T1DM patients [26]. Subsequently, several longitudinal studies (with 3-7 years of follow-up) revealed an accelerated decline in lung function in patients with T1DM or T2DM, mainly in cases with inadequate glycemic control [27-31]. The findings of these studies showed that the reduction in the lung function of diabetic patients characterized by low forced expiratory volume in one second is two to three times faster than that of normal nonsmoking subjects $(71 \mathrm{ml} /$ year reduction compared to an 


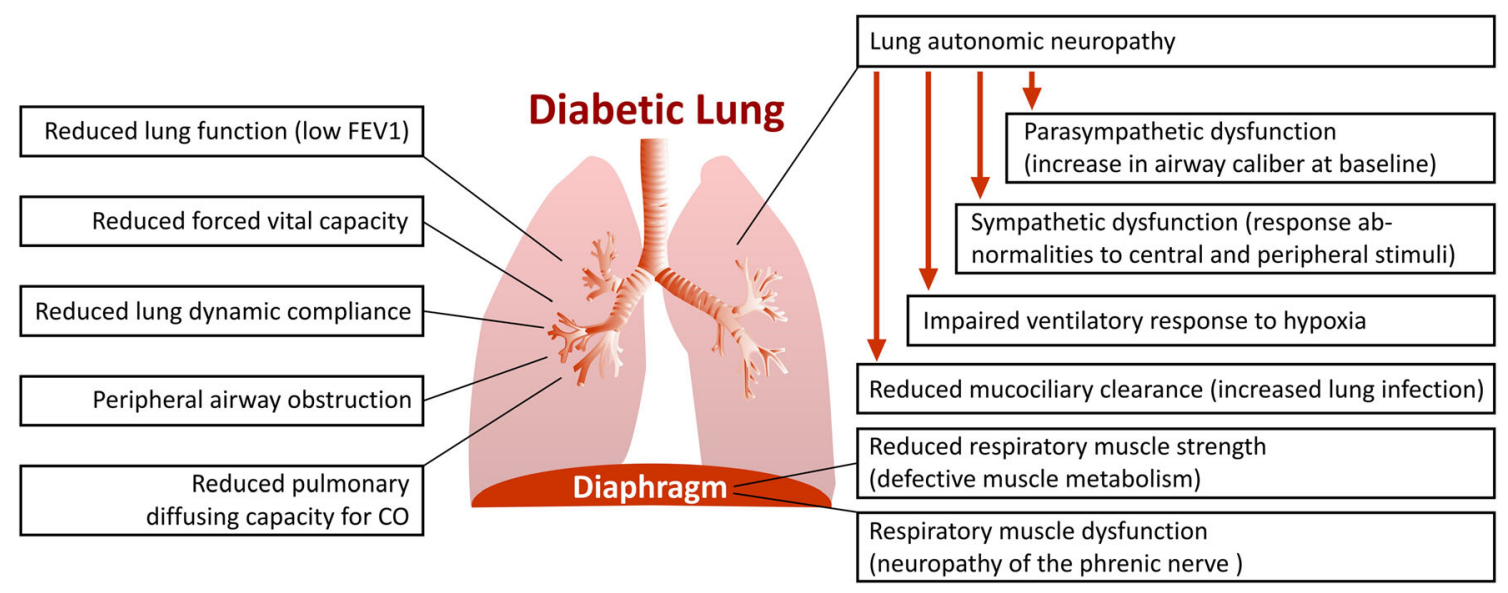

Fig. 1 Respiratory tract abnormalities in patients with diabetes mellitus. Several functional abnormalities in the respiratory tract are proven in patients with diabetes mellitus. Reduced lung function of diabetic patients characterized by low forced expiratory volume in one second (FEV1) is two to three times faster than that of normal nonsmoking subjects. Reduced forced vital capacity and lung dynamic compliance, peripheral airway obstruction as well as reduced pulmonary diffusing capacity for carbon monoxide $(\mathrm{CO})$ has been reported in diabetic patients. Pulmonary autonomic neuropathy in diabetic patients, results in an

expected decline in healthy nonsmokers of $25-30 \mathrm{ml} /$ year) [27-31]. In line with the reduction in forced expiratory volume in one second, some studies have found a reduction in forced vital capacity and lung dynamic compliance as a result of peripheral airway obstruction [32-34]. With respect to reduced lung function and volumes, several functional abnormalities in the respiratory tract of diabetic patients have been reported. A reduced pulmonary diffusing capacity for carbon monoxide has been reported in both T1DM and T2DM [32-34]. Diffusing capacity for carbon monoxide reduction in diabetic patients is attributed to thickening of the basal lamina of pulmonary capillaries, microangiopathy of pulmonary capillaries, reduced pulmonary capillary blood volume, impaired ventilatory response to hypoxia. In diabetic patients, sympathetic neuropathy impairs pulmonary function, resulting in ventilatory response abnormalities to central and peripheral stimuli. In this line, parasympathetic neuropathy may cause an increase in airway caliber at baseline. Pulmonary autonomic neuropathy reduces mucociliary clearance and prone the lung to the infections. Reduced respiratory muscle strength due to defective muscle metabolism and neuropathy of the phrenic nerve promote respiratory muscle dysfunction in diabetic patients

cardiac autonomic nervous system dysfunction, nonenzymatic protein glycation in the extracellular matrix and local oxidative stress in the lung endothelium [13, 35-39].

Pulmonary autonomic neuropathy is very common in diabetic patients, affecting their control of ventilation with an impaired ventilatory response to hypoxia but not to hypercapnia [12, 40, 41]. Sympathetic dysfunction in bronchial innervation impairs pulmonary function, resulting in ventilatory response abnormalities to central and peripheral stimuli in diabetic patients [42]. Reduction in the parasympathetic bronchomotor tone may cause an increase in airway caliber at baseline in diabetic patients due to autonomic neuropathy [43]. Pulmonary autonomic neuropathy, which reduces

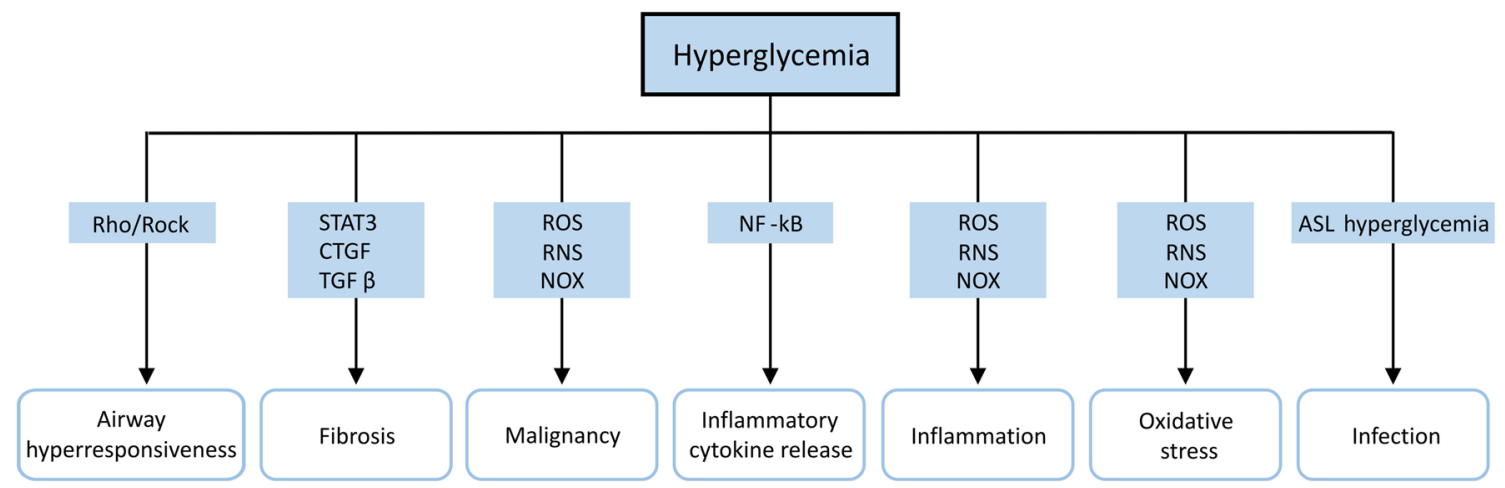

Fig. 2 Schematic representation of hyperglycemia-induced lung diseases. Hyperglycemia promotes airway hyperresponsiveness via the Rhoassociated protein kinase (Rock) pathway. Hyperglycemia accelerates lung fibrosis through the activation of signal transducer and activator of transcription 3 (STAT3), connective tissue growth factor (CTGF) and transforming growth factor beta (TGF $\beta$ ). Hyperglycemia increases cancer cell growth, chronic inflammation, inflammatory cytokine release and oxidative stress through activation of the nuclear factor kappa-lightchain-enhancer of activated B-cells $(\mathrm{NF} \kappa \mathrm{B})$ pathway and NADPH oxidase (NOX) as well as the production of reactive oxygen species (ROS) and reactive nitrogen species (RNS). Higher glucose concentrations in airway surface liquid (ASL) and lung immune cell dysfunction due to hyperglycemia promote a susceptibility to pulmonary infections 


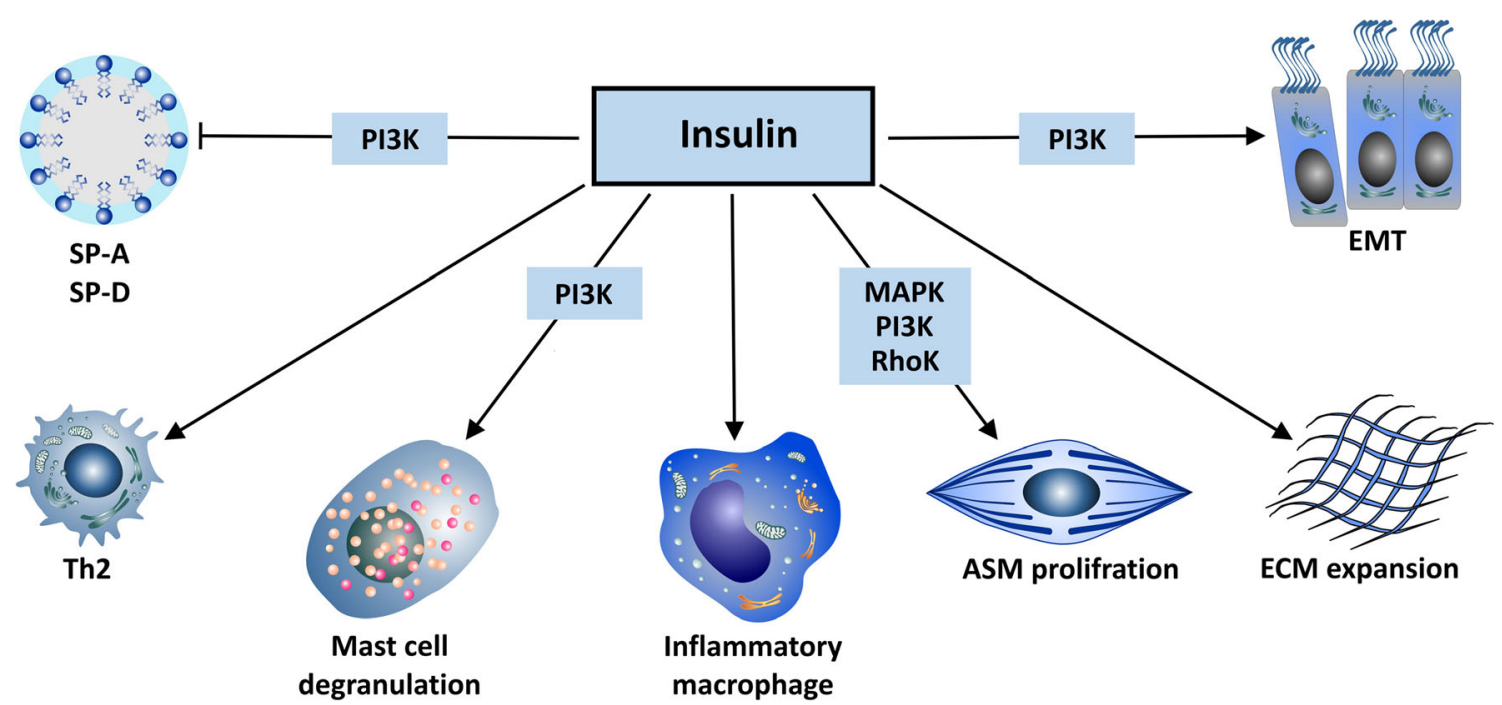

Fig. 3 Schematic representation of insulin effects on the lung. Insulin inhibits surfactant protein A (SP-A) and surfactant protein D (SP-D) production via a phosphoinositide-3-kinases (PI3K) pathway. Insulin inhibits the proliferation of T helper cell type 1 (Th1) and shifts T cells towards a Thelper cell type 2 (Th2)-type response. Insulin promotes mast cell survival, degranulation and histamine release via a PI3K pathway and

mucociliary clearance, might explain the vulnerability of diabetic patients to lung infections $[44,45]$.

Recent studies have suggested a reduction in respiratory muscle strength in T1DM and T2DM mainly because of defective muscle metabolism $[25,46,47]$. The endurance of the respiratory muscles is reduced in diabetic patients, and this deficit is inversely correlated to the degree of metabolic control, as indicated by the $\mathrm{HbA}_{1 \mathrm{c}}$ (glycated hemoglobin) level [25]. Neuropathy of the phrenic nerve alters bronchial reactivity, promoting respiratory muscle dysfunction in diabetic patients [48]. Respiratory muscle disorders, due to defective muscle metabolism or phrenic neuropathy, reduce lung volumes and accelerate lung restrictive complications in diabetic patients [45-48]. Cardiopulmonary exercise tests have revealed that maximal workload, maximal oxygen consumption and maximal heart rate are all severely reduced in diabetic patients, which explains the limitation of physical exercise capacity in these patients $[49,50]$.

Furthermore, systemic chronic inflammation associated with oxidative stress and loss of antioxidant capacity may cause lung endothelial dysfunction and thickening of the lung interstitium in patients with DM $[13,51,52]$. A large capillary network in the lung (surface area $=140 \mathrm{~m}^{2}$ ), characterized by a great microvascular reserve, is the main protective mechanism against DM-induced pulmonary complications. Because of the large pulmonary reserve, micro- and macrovascular dysfunctions due to diabetes develop later in the lung than in other organs. However, the association of DM with primary pulmonary disease may cause severe loss of lung microvascular reserve with an increased risk of pulmonary abnormalities $[53,54]$. The association of DM and pulmonary diseases, activates pulmonary inflammatory macrophages. Insulin proliferates and contracts airway smooth muscle cells (ASMs) via mitogen-activated protein kinase (MAPK), Rho kinase and PI3K pathways. Insulin increases the deposition of extracellular matrix (ECM) in the lung and promotes epithelial-mesenchymal transition (EMT) and fibrosis via the PI3K/ protein kinase $\mathrm{B} \beta$-catenin pathway

considering susceptibility, prevalence, progression and severity, will be discussed in the following chapter of this review.

\section{$3 \mathrm{DM}$ and lung cancer}

Previous studies have shown a positive correlation between DM and colorectal, breast, endometrial, kidney and pancreatic cancer [55-58]. Hyperinsulinemia (either endogenous due to insulin resistance in T2DM or exogenous due to administered insulin in T1DM) may increase cell survival and proliferation related to insulin and insulin-like growth factor [59-61]. Concomitant to hyperinsulinemia, hyperglycemia may promote cancer cell growth, pro/antiinflammatory cytokine imbalance, chronic inflammation, oxidative stress and anticancer immunity suppression [13,62] (Fig. 2). Although DM and lung cancer share similar risk factors, including age, smoking and alcohol, studies assessing the causative association of DM and lung cancer have yielded conflicting results [62-66]. A large retrospective study from the United Kingdom showed a lower cancer incidence rate in a diabetic population than in the general healthy population [66]. The authors assumed that the difference may be partly due to the reduced life expectancy of individuals with DM compared with that of the general population, resulting in a lower chance to develop lung cancer [66]. However, a meta-analysis of observational studies from Lee et al. (2013) showed a higher incidence of lung cancer in diabetic women [67]. The correlation of DM and lung cancer did not reach a significant level for male patients in this study [67]. Dankner et al. (2018) recently showed a mildly higher risk for lung cancer in diabetic patients with poor glycemic 
control [68]. Analyses of the survival rate of patients with both lung cancer and DM compared with that in lung cancer patients without DM have yielded conflicting results [69-74]. Some studies have shown an increase [69, 70], some studies have shown a decrease [71, 72], and other studies have reported no significant change $[73,74]$ in the survival rate of patients suffering from both lung cancer and DM compared with that in lung cancer patients without DM. A lower rate of metastasis in lung cancer patients with DM has been reported in some studies [70, 73]. The antineoplastic effects of some antidiabetic medications, especially metformin, have been suggested to partially correlate with a reduced incidence and progression of lung cancer in diabetic patients [75-77]. However, the underlying biological mechanisms are not clear, and the results of these studies are still contradictory [75-80]. Further well-designed prospective population-based studies with high-quality databases are needed to compare the incidence of lung cancers between individuals with high circulating insulin levels and/or hyperglycemia with or without diabetes and nondiabetic individuals with normal insulin sensitivity and/or normoglycemia. To reduce heterogeneity across studies, common risk factors such as type and duration of DM, body weight, physical activity, age, sex, ethnicity, diet, therapy, degree of glycemic control, tobacco smoke and alcohol consumption need to be considered in these investigations.

\section{$4 \mathrm{DM}$ and lung infection}

A wide range of neutrophil and macrophage functions, including chemotaxis, adherence, phagocytosis, ability to kill phagocytosed microorganisms with free radicals and respiratory burst are impaired in DM $[81,82]$. A reduced complement system $\mathrm{C} 4$ and humoral immunity associated with a reduced number and response of $\mathrm{T}$ cells increase the susceptibility of diabetic patients to infection [83, 84]. Furthermore, hyperglycemia and insulin resistance impair collective surfactant D-mediated host defenses of the lung in T2DM [85]. Loose junctions between airway epithelial cells, which increase the transepithelial glucose gradient along with an increase in the glucose concentration of the airway surface liquid due to hyperglycemia, may dampen the airway defense against infection, resulting in lung bacterial overgrowth in DM [86] (Fig. 2). Staphylococcus aureus and Streptococcus pneumoniae; influenza virus; opportunistic pathogens such as Klebsiella pneumoniae, Pseudomonas aeruginosa; and fungal infections with Mucorales and Aspergillus species, are frequent causes of lung infection in DM [83, 87, 88]. Hospitalization during the influenza epidemic was found to be six times higher in diabetic patients than in nondiabetic individuals [89]. It has been reported that pneumonia has the greatest prevalence, incidence and severity among diabetic patients with elevated $\mathrm{HbA}_{1 \mathrm{c}}$ levels [90]. Furthermore, poor glycemic control in DM may increase the risk of pneumoniarelated hospitalization in these patients [90]. DM is associated with a poor prognosis, increasing the rate of pleural effusion and mortality in community-acquired pneumonia [91]. Initial administration of the first antibiotic given not later than $8 \mathrm{~h}$ of triage is associated with fewer complications and lower mortality in diabetic patients with pneumonia [92]. Some pharmacological studies have shown that treatment with angiotensinconverting-enzyme inhibitors or statins is associated with a significant reduction in the risk of pneumonia in both type 1 and type 2 diabetic patients $[93,94]$. However, the mechanisms behind this protective effect are unclear. The risk of pneumococcal infection remains higher even after vaccination in diabetic patients, presumably due to low vaccine uptake or low effectiveness of the available vaccines [95]. The higher rate of lung infections in diabetic patients is mainly due to hyperglycemia which adversely affecting immune system function, increasing diabetic patients morbimortality. Further studies are necessary to mechanistically evaluate the role of airway glucose hemostasis treatments and of antihypertensive, lipid lowering and immune system-modifying medications on improving immune system function and reducing the respiratory infection frequency in DM patients.

\section{$5 \mathrm{DM}$ and pulmonary tuberculosis}

It has been shown that a reduction in the immune response associated with DM may increase the risk of developing active tuberculosis by approximately three-fold [96-98]. Several studies have shown that $10 \%-30 \%$ of patients with tuberculosis may also suffer from DM [97-100]. Diabetic patients are also prone to develop drug-resistant tuberculosis resulting in antituberculosis treatment failure, disease relapse after the completion of treatment and increased mortality [101-103]. Alveolar residential cells (monocytes and macrophages) play an important role in the pathogenesis of tuberculosis [104]. Mycobacterium tuberculosis infects alveolar macrophages, and the pathogen accumulates and replicates in macrophages, resulting in cellular death and shedding of bacteria to other pulmonary cells [105]. In diabetic patients, reduced opsonization, and binding and phagocytotic activity of monocytes towards Mycobacterium tuberculosis may increase the susceptibility of these patients to tuberculosis [103, 106, 107]. The role of neutrophils, natural killer T cells and dendritic cells in the context of DM and tuberculosis is not clear [108, 109]. Studies on the role of the adaptive immune system in diabetic patients with tuberculosis have led to conflicting results. Some studies have shown a reduction in $\mathrm{T}$ cell proliferation and $\mathrm{T}$ cell-associated cytokine production, especially interferon $\gamma$, in diabetic patients with tuberculosis $[110,111]$. However, other studies have found higher numbers of T helper type 1 and 17 cells but lower frequencies of $\mathrm{T}$ regulatory cells and a higher 
production of related cytokines, including interferon $\gamma$, tumor necrosis factor- $\alpha$, Interleukin (IL)-17A/F, IL-2, IL-1 $\beta$, granulocyte macrophage colony-stimulating factor and IL-5, IL-10 and transforming growth factor $\beta$ (TGF $\beta$ ), in diabetic patients with tuberculosis than in matched nondiabetic tuberculosis patients [112-114]. Type 1 and 17 cytokine production was positively correlated with $\mathrm{HbA}_{1 \mathrm{c}}$ levels in diabetic patients with tuberculosis [114]. T2DM does not show any effect on the numbers or subset distribution of $\mathrm{CD}^{+} \mathrm{T}$ and $\mathrm{NK}$ cells, but it alters the $\mathrm{CD} 8^{+} \mathrm{T}$ and $\mathrm{NK}$ cell response to Mycobacterium tuberculosis [115]. T2DM patients with active tuberculosis show higher frequencies of mycobacterial antigen-stimulated $\mathrm{CD} 8^{+} \mathrm{T}$ cells and NK cells expressing type 1 and type 17 cytokines [115]. However, cytotoxic markers of $\mathrm{CD} 8^{+} \mathrm{T}$ cells and NK cells are decreased in these patients [115]. It is assumed that the higher frequencies of $\mathrm{T}$ cell response and altered phenotype and function in $\mathrm{CD} 8^{+} \mathrm{T}$ cells and NK cells in diabetic patients with tuberculosis yields a less functional but excessive immune-mediated pathology than that in nondiabetic tuberculosis patients. Tuberculosis susceptibility in DM needs to be explored from immunological and biochemical aspects. The molecular mechanism of hyperglycemia and insulinemia on macrophage and lymphocyte phagocytic, chemotactic and antigen presentation responses to Mycobacterium tuberculosis needs to be investigated in more detail. Epidemiological studies on the association of DM and tuberculosis should distinguish between T1DM and T2DM to determine the effect modification by age and type of diabetes.

\section{DM and cystic fibrosis}

$\mathrm{DM}$ is the most common and life-threatening complication of cystic fibrosis due to pancreatic insufficiency and the abnormal timing and delayed and blunted secretion of insulin [116]. Cystic fibrosis-related diabetes (CFRD) reduces survival and increases the mortality in cystic fibrosis patients with diabetes compared with that in nondiabetic cystic fibrosis patients [117]. There is a difference in the pattern of diabetes in CFRD compared to that of T1DM and T2DM, but the micro- and macrovascular complications of CFRD, except cardiovascular disease, appear to be similar to those seen in other types of diabetes [118]. CFRD adversely affects lung function (average forced expiratory volume in one second of $52 \%$ in cystic fibrosis patients with diabetes compared with $72 \%$ in nondiabetic patients) [119-121]. A decline in the lung function of CFRD patients is seen for several years prior to the diagnosis of CFRD $[122,123]$. The severity of pulmonary dysfunction is positively correlated with the degree of insulin deficiency (causing glucose intolerance and protein catabolism) in patients with CFRD [121]. Some studies have found that insulin treatment improves lung function and increases forced expiratory volume in one second in patients with CFRD [124-127]. Staphylococcus aureus and Pseudomonas aeruginosa coinfections are associated with CFRD, which accelerates the pulmonary deterioration and lung function decline in CFRD patients [128]. It still needs to be clarified whether the dampened immune function due to hyperglycemia (as discussed above in DM and lung infection) is also partly responsible for the Staphylococcus aureus and Pseudomonas aeruginosa coinfections in CFRD patients. Further basic and clinical studies are required to investigate the relationships of hyperglycemia, insulin deficiency and long-term insulin therapy with pulmonary function in CFRD.

\section{DM and asthma}

Asthma is a chronic inflammatory disease mediated by T helper type 2 (Th2) cells [129]. On the other hand, T1DM is mediated by Th1 cells. Considering the Th1/Th2 paradigm (cytokines from either the Th1 or Th2 phenotype exerting suppressive activities on the development and activity of the other phenotype), previous findings have shown a negative association between T1DM and asthma [130-133]. A recent case-cohort study among Finnish children showed that participants with previously diagnosed asthma were at an increased risk of subsequent development of T1DM but that children with previously diagnosed T1DM presented a decreased risk of subsequent development of asthma, suggesting a distinct interrelation of the sequential appearance of these two diseases [134]. Overall, there is increasing evidence for a positive correlation between the occurrence of T1DM and symptoms of asthma at the population level [135-137]. It is assumed that factors influencing the susceptibility to the coincident occurrence of asthma and T1DM may cluster in countries, attributed to genetic and/or early environmental exposures [135-137]. It has been suggested that autoimmune diseases such as T1DM and allergic diseases such as asthma may have some common immunopathogenetic mechanisms, influenced by environmental factors such as lifestyle and living conditions [138]. A positive correlation between $\mathrm{HbA}_{1 \mathrm{c}}$ levels and asthma occurrence has been reported among young individuals with T1DM [139]. Rachmiel et al. (2006 and 2011) showed that patients suffering from T1DM and asthma present a unique intermediate Th1/Th2 cytokine profile, combining features of both diseases [140, 141]. Animal studies have revealed that the coinduction of T1DM and asthma significantly reduces airway inflammation and airway hyperresponsiveness [142-146]. Decreased release of sensory neuropeptides; reduced influx of eosinophils, number of degranulated mast cells and histamine release; and increased inhibitory neuronal muscarinic receptor 2 function in the lung were the main suggested mechanisms for the ameliorative effect of DM in asthma models [142-146]. Findings on the 
role of T2DM and asthma prevalence are inconsistent, most likely due to different study designs and populations [147-150]. However, T2DM and obesity may increase the risk of asthma to two and three times greater than that in normal subjects, respectively $[151,152]$. Obesity decreases the effectiveness of asthma therapy and increases the rate of hospitalizations due to asthma exacerbations to levels nearly five times greater than those of asthmatic subjects without obesity [153]. It has been shown that gestational DM and obesity are associated with an increased risk for childhood asthma $[154,155]$. It is now clear that insulin can inhibit surfactant $\mathrm{A}$ and $\mathrm{D}$ production via a phosphoinositide-3-kinase pathway, shift $\mathrm{T}$ cells towards a Th2-type response, promote mast cell survival and degranulation via a phosphoinositide-3-kinase pathway, activate pulmonary inflammatory macrophages, and proliferate and contract airway smooth muscle cells via the mitogen-activated protein kinase, Ras homologue kinase and phosphoinositide-3-kinase pathways [22, 23, 156-160] (Fig. 3). Increasingly, evidence suggests that DM and asthma are multiply linked through various pathophysiological mechanisms. It is concluded that not only type 1 and type 2 diabetic patients but also offsprings of diabetic mothers are at increased risk of developing asthma. Indeed, there is an increasing demand to investigate the underlying molecular mechanisms by which different types of DM and obesity, hyperglycemia and hypo/hyperinsulinemia affect asthma induction, progression and severity.

\section{$8 \mathrm{DM}$ and chronic obstructive pulmonary disease (COPD)}

Chronic inflammation and systemic oxidative stressassociated with increased levels of CRP, TNF- $\alpha$, IL-1, IL-6, and fibrinogen - are shared features in COPD and DM [13, 161]. However, the association and interplay between DM and COPD are not clearly understood. Ehrlich et al. (2010) demonstrated a higher incidence of COPD in diabetic patients with higher body mass index $(29.80 \pm 6.48)$ and $\mathrm{HbA}_{1 \mathrm{c}}(>6.7 \%)$ [65]. It has been recently shown that the pulmonary function in diabetic patients with $\geq 10$ pack-years of smoking is reduced compared to that in nondiabetic smokers [162]. This pulmonary malfunction is associated with significant reductions in activity-related quality of life and exercise capacity [83]. DM may increase the risk of COPD exacerbation and mortality [163, 164]. Hyperglycemia, i.e., random blood glucose $\geq 7 \mathrm{mmol} / \mathrm{l}$ is associated with poor outcomes and increased COPD-related morbidity and mortality in hospitalized patients in the intensive care unit [165]. Hyperglycemia (i.e., random blood glucose $\geq 7 \mathrm{mmol} / \mathrm{l}$ ) upon presentation to the intensive care unit was found to be a useful predictor of poor outcomes and to confer the greatest risk of treatment failure with noninvasive ventilation in patients with severe COPD [166].
However, the role of COPD as a risk factor for DM remains controversial [167]. Some studies have shown a higher risk of DM in patients with COPD compared with that in control subjects $[168,169]$, whereas other studies have not found any association between COPD and DM [170, 171]. Antiinflammatory treatment with corticosteroids (locally and systemically) is used in patients with COPD to improve their quality of life and reduce the frequency of exacerbations. It has been shown that inhaled corticosteroids in patients with COPD are not associated with an increased risk of new onset $\mathrm{DM}$, hyperglycemia or a significant change in $\mathrm{HbA}_{1 \mathrm{c}}$ levels $[172,173]$. On the other hand, metformin treatment over a $2-$ year follow-up period in patients with coexisting DM and COPD reduced emergency room visits and hospitalization, especially in low-complexity COPD [174]. A recent cohort study showed that metformin treatment reduces the risk of all-cause mortality in patients with coexisting T2DM and either stable or exacerbated COPD [175]. It is realized that DM may increase the risk of COPD, worsening the quality of life and increasing the rate of exacerbation and mortality in COPD patients. However, the complex interaction between DM and COPD requires more detailed prospective population-based investigations, considering which disease (DM or COPD) appears first, as well as the type and duration of DM and severity of COPD, glycemic condition of the patients, smoking status and treatment strategies in these diseases.

\section{DM and acute lung injury (ALI) / acute respiratory distress syndrome (ARDS)}

The reports on the association of DM and ALI or ARDS reveal inconsistent findings [176-182]. It has been shown that T2DM does not affect the lung physiopathology in patients with ARDS [177]. Recently, a large, global observational study found no association between DM and ARDS progression or hospital mortality from ARDS [178]. However, many studies have shown that both T1DM and T2DM may prevent the development of ARDS in patients with predisposing ARDS risk factors [166, 182-186]. However, the beneficial effect of DM on ARDS development does not reduce the mortality among patients in whom ARDS develops [176, 182, 187]. The preventive mechanism of DM against ARDS development is not completely understood. Studies on experimentally induced DM show that the preventive effect may be attributed to decreased neutrophil numbers and function, impaired nuclear factor K-light-chain-enhancer' of activated Bcells activation, reduced superoxide generation, insulin growth factor and its receptor deficiency, leptin resistance and lower concentrations of inflammatory cytokines such as tumor necrosis factor- $\alpha$, IL- $1 \beta$, IL- 6 , and prostaglandin E2 [188-194]. It has been assumed that insulin may modulate the development of ALI/ARDS in DM. In clinical studies, 
intensive insulin therapy shortened the time of mechanical ventilation and decreased mortality and/or morbidity rates among hyperglycemic patients with prolonged intensive care unit stays, regardless of whether they had a history of diabetes or not $[195,196]$. In this respect, experimental studies have confirmed the beneficial effect of insulin therapy in different animal models of ALI/ARDS [197, 198]. However, the suggested protective effect of insulin therapy and other antidiabetic agents (including peroxisome proliferator-activated receptor gamma agonists such as rosiglitazone, metformin and dipeptidyl peptidase IV inhibitor sitagliptin), angiotensinconverting-enzyme inhibitors and statins in animal models of ALI/ARDS needs to be explored in humans [197-204]. In sum, it is shown that compared to other pulmonary disorders, DM seems to be protective against ALI/ARDS development with unclear mechanism. However, more well-designed and well-conducted clinical investigations, considering the type and severity of DM, are needed to determine the mechanism by which DM or DM treatments may affect the development of ALI/ARDS in these patients.

\section{$10 \mathrm{DM}$ and pulmonary hypertension}

DM causes systemic macro- and microvascular dysfunction, but considering the large pulmonary vascular network, the impact of DM on the pulmonary vasculature is still not clear $[205,206]$. Epidemiological studies have revealed that diabetic patients are at higher risk for developing pulmonary hypertension associated with markedly worse survival [207-210]. Animal experiments have shown that experimental streptozotocin (STZ)-induced T1DM causes pulmonary vascular endothelial dysfunction through oxidative stress [211, 212]. Insulin resistance and undiagnosed DM are common in patients with pulmonary hypertension $[213,214]$. In nondiabetic patients with pulmonary hypertension, a significant positive correlation was observed between $\mathrm{HbA}_{1 \mathrm{c}}$ levels and worse long-term prognosis [215]. Gestational diabetes may be a risk factor for pulmonary hypertension in newborns [216]. Recently, Grinnan et al. 2016 reviewed the possible mechanisms of DM-induced pulmonary hypertension based on the existing research information [217]. The suggested mechanisms include right ventricular failure [218], increasing endothelin levels, platelet-derived growth factor and TGF- $\beta$ production $[219,220]$, higher insulin-like growth factor expression and lower peroxisome proliferator-activated receptor gamma expression [221, 222], reduced endothelial nitric oxide synthase activity and nitric oxide production [223] and reduced prostacyclin production [224]. More detailed human and animal studies are recommended to elucidate the exact underlying mechanism that may spare the pulmonary vasculature from (or make it prone to) toxic effects of DM, such as hyperglycemia, hyperinsulinemia, oxidative stress and chronic inflammation. The incidence of pulmonary hypertension in different types of DM should be defined in more robust epidemiological studies.

\section{$11 \mathrm{DM}$ and pulmonary fibrosis}

Aging is an important contributing factor in both DM and pulmonary fibrosis, increasing the possibility that lifestylerelated diseases such as DM and/or obesity may affect the initiation and/or progression of pulmonary fibrosis [225, 226]. Increased thickness of alveolar capillary walls, alveolar walls and pulmonary arteriolar walls, representing lung fibrotic histopathological changes, have been reported in autopsied lungs from diabetic patients [227]. However, in contrast to this study, no differences in the alveolar walls or intimal fibrosis and medial thickening of small vessels in the autopsied lungs were seen between DM and control groups [228]. Specific types of nodular fibrosis, a combination of inflammatory cells and excessive deposition of collagen and extracellular matrix, were the only typical changes observed in the lungs of these patients [228]. It has been shown that alveolar epithelial cells and the endothelial capillary basal lamina are significantly thicker in diabetic patients than in control subjects [229, 230]. A first Japanese case-control study showed that DM increases the risk for developing pulmonary fibrosis [231]. A case-control study from the United Kingdom found an association between IPF and DM, the strongest association being with insulin use [225]. Another Mexican case-control study showed that T2DM is the most important independent risk factor associated with pulmonary fibrosis [232]. Furthermore, it has been shown that T1DM is also an independent risk factor for pulmonary fibrosis [233]. Two Korean case-control studies demonstrated the association of DM with IPF $[234,235]$. A higher prevalence of hypertension, cardiovascular disease, and other malignancies, excluding lung cancer, has been shown in IPF patients with DM than in IPF patients without DM [235]. A Danish cohort study showed that DM is the third most frequently observed comorbidity of pulmonary fibrosis after cardiovascular disease and arterial hypertension [236]. This study suggested for the first time that DM significantly increases mortality in IPF patients [236]. Advanced glycation end product -modified protein accumulation has been shown in lung macrophages in remodeling lesions of pulmonary fibrosis, suggesting that chemical modification by AGE might be involved in DM-induced pulmonary fibrosis [237]. Taking all these findings together, it may be concluded that DM is one of the main comorbidities in patients with IPF (Fig. 4). The recognition and management of comorbidities in IPF may limit disease progression and increase survival in these patients. The pathogenic mechanisms implicated in the association of DM and IPF are currently not understood and remain to be elucidated in further clinical and 
Nonenzymatic glycation of collagen and elastin Expansion of the interstitial tissue

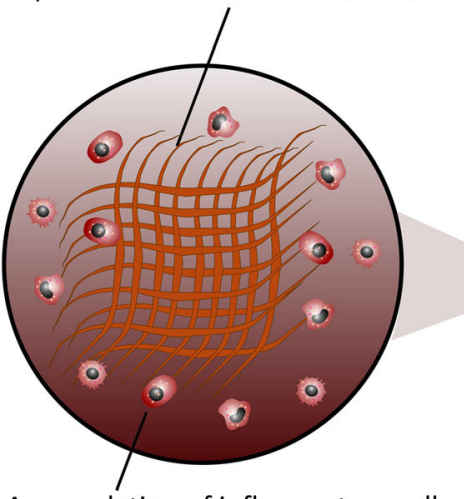

Accumulation of inflammatory cell

Pro-inflammatory / Pro fibrotic cytokines release

Oxidative stress

Fig. 4 Schematic representation of DM-induced pulmonary fibrosis. Hyperglycemia, the main feature of both T1DM and T2DM, increases the accumulation of advanced glycation end product (AGE)-modified proteins, resulting in lung structural remodeling in pulmonary fibrosis. Excessive production of extracellular matrix (ECM) components such as collagen and elastin, and particularly, nonenzymatic protein glycation of the ECM due to hyperglycemia, results in matrix stiffening, which irreversibly remodels the lung tissue structure and promotes the progression of pulmonary fibrosis. Micro- and macroangiopathy, narrowing of the

experimental research. The following chapter focuses on the current in vitro and in vivo experimental studies that have been conducted to investigate the possible mechanisms of DM-induced pulmonary fibrosis.

\section{Mechanisms involved in DM-induced pulmonary fibrosis in vitro and in vivo}

Experimental investigations have shown an increase in the lung volume and weight in a STZ-induced rat model of T1DM [238]. Increases in the amount of collagen, elastin and hydroxyproline along with reduced breakdown of glycated connective tissue proteins are involved in the promotion of lung fibrosis by diabetes [238-240]. In a STZ-induced diabetic mouse model, hyperglycemia-induced lung fibrosis was more severe than that in mice treated with bleomycin (a standard drug for experimental lung fibrosis induction in animal models) [239]. Furthermore, enlargement of air spaces, increased alveolar surface area and a greater number of alveoli have been reported in the rat model of DM [240]. AGE accumulation in the lung due to hyperglycemia may increase lung oxidative stress, resulting in lung fibrotic changes [241]. Hyperglycemia induces oxidative stress, ROS and reactive nitrogen species generation, and impairment of the capacity of the antioxidative defense system are the major causes of T1DM-induced lung fibrosis [242, 243]. Nitric oxide and peroxynitrite are considered to play a critical role in lung fibrotic pathogenesis in STZ-induced T1DM [244]. alveolar space, flattening of the alveolar epithelium and thickening of the alveolar basal lamina are among the structural modifications in diabetic lung fibrosis. Infiltration of both innate and adaptive immune cells into the lung tissues of diabetic individuals leads to a profound release of numerous proinflammatory/profibrotic cytokines, resulting in pulmonary fibrotic responses. Reactive oxygen species (ROS) such as superoxide and reactive nitrogen species such as peroxynitrite cause cellular and subcellular structural damage within the lung, accelerating the progression of pulmonary fibrosis

Inflammatory cell infiltration into the lungs of both experimental type 1 and type 2 diabetic animals may also play important roles in the development of DM-induced lung fibrosis $[245,246]$. Enlargement of the interstitium and increased thickness of the alveolar walls and basement membrane have been reported in OVE26 transgenic mice, which develop diabetes spontaneously 2 to 3 weeks after birth [247]. Plasminogen activator inhibitor-1 is increased in STZinduced diabetic mice that develop lung fibrosis through impairment of the coagulation and fibrinolytic systems [233, $248,249]$. TGF- $\beta 1 /$ Smads signaling, the most important signaling pathway in the initiation and progression of pulmonary fibrosis, is increased in the lungs of STZ-induced diabetic rats [245]. An increase in signal transducer and activator of transcription 3 and connective tissue growth factor in the STZinduced rat model of diabetes may result in lung damage associated with fibrosis [250]. Treatment with insulin normalizes hyperglycemia and ameliorates signal transducer and activator of transcription 3 or connective tissue growth factor expression in diabetic rats, suggesting a role for hyperglycemia in the pathogenesis of lung fibrosis [250] (Fig. 2). It has been shown that angiotensin II plays a critical role in diabetic lung fibrosis, at least in part through NADPH oxidasemediated nitrosamine damage in two models of STZinduced T1DM and OVE26 diabetic mice [251]. However, angiotensin (I-VII), by opposing the actions of angiotensin II, reduces systemic inflammation, decreases the total amount of collagen in the lung and ameliorates lung pathological remodeling and fibrosis, which are associated with T2DM 
[252]. Platelets are the main source of cytokines, such as TGF- $\beta$ and platelet-derived growth factor, which are implicated in the development of pulmonary fibrosis [253]. Platelet dysfunction and platelet granule abnormalities may contribute to DM-induced lung fibrosis through the initiation of inflammation, oxidative stress and the secretion of profibrotic cytokines such as TGF- $\beta$ and platelet-derived growth factor [254]. Hyperinsulinemia, a major feature of T2DM, increases collagen deposition in the lungs and stimulates airway hyperresponsiveness through increasing contractile effects on airway smooth muscle cells [255]. Furthermore, hyperinsulinemia promotes epithelial-mesenchymal transition and fibrosis through activation of the phosphoinositid-3kinasen/protein kinase B $\beta$-catenin pathway and produces deleterious structural and functional changes in the lung [255] (Fig. 3). Necropsy analysis of diabetic cats confirmed a significant increase in pulmonary fibrosis in these animals compared with that in control nondiabetic cats [256]. Taken together, these clinical and nonclinical studies suggest that diabetes may be an important risk factor for the initiation and progression of pulmonary fibrosis, albeit through unclear mechanisms.

\section{Conclusion and outlook}

Diabetes mellitus-related complications in multiple organs, such as those of the cardiovascular system, central nervous system, kidneys, nerves and retina, have been extensively studied in both human and animal models. Despite emerging clinical reports on the diabetic lung, the mechanism involved in diabetes-induced pulmonary disorders has been poorly studied. Therefore, intense efforts are required to better identify and quantify pulmonary risks in patients with DM, not only by focusing on the description of the statistical relation between DM and lung diseases but also through investigating the mechanisms for these comorbidities. Targeting multiple risk factors associated with DM is essential to curbing the growing prevalence and progression of pulmonary complications in diabetic patients. Although the optimization of glycemic control plays an important role in improving pulmonary complications, the direct role of insulin and other antidiabetic drugs in the respiratory tract needs to be clarified in future research. Clinical and experimental studies are needed to better understand the lung disease process in diabetic patients in order to improve medical management and the prevention of pulmonary complications in these patients. Multifaceted investigations utilizing suitable translational animal models and large prospective human population-based studies will help scientists and clinicians translate the acquired knowledge into effective and meaningful clinical interventions. There is an increased population with undiagnosed DM, which can cause serious health problems, particularly lung comorbidities. From a public health perspective, the early treatment of lung comorbidities in patients with diagnosed and undiagnosed DM may have a strong potential to improve the quality of life and survival in these patients.

Acknowledgments The authors thank Peter M. Weber (University of Tübingen, Tübingen, Germany) for the excellent illustration. S.K. is supported by fortüne grant funding from the University Hospital Tübingen (grant No: 2458-0-0). B.N. and V.L. are supported by Deutsche Forschungsgemeinschaft (grant NU: 53/9-2).

Author contributions Conceptualization: SK, BN.

Writing - original draft: SK, VL.

Writing - review \& editing: SK, VL, BN.

\section{Compliance with ethical standards}

Conflict of interest The authors declare that there is no conflict of interest regarding the publication of this article.

\section{References}

1. Shaw JE, Sicree RA, Zimmet PZ. Global estimates of the prevalence of diabetes for 2010 and 2030. Diabetes Res Clin Pract. 2010;87:4-14.

2. NCD Risk Factor Collaboration (NCD-RisC). Worldwide trends in diabetes since 1980: a pooled analysis of 751 population-based studies with 4.4 million participants. Lancet. 2016;387:1513-30.

3. International Federation Diabetes. Diabetes Atlas. 6th ed. International Diabetes federation. 2013;28:49.

4. American Diabetes Association. Diabetes Care. 2. Classification and Diagnosis of Diabetes: Standards of Medical Care in Diabetes-2018. 2018;41:13-27.

5. Diabetes Control and Complications Trial (DCCT)/Epidemiology of Diabetes Interventions and Complications (EDIC) Study Research Group. Intensive diabetes treatment and cardiovascular outcomes in type 1 diabetes: the DCCT/EDIC study 30-year follow-up. Diabetes Care. 2016;39:686-93.

6. Concannon P, Rich SS, Nepom GT. Genetics of type 1A diabetes. N Engl J Med. 2009;360:1646-54.

7. Greenhill C. Unravelling metformin's mechanism of action. Nat Rev Endocrinol. 2018;14:564.

8. Rena G, Hardie DG, Pearson ER. The mechanisms of action of metformin. Diabetologia. 2017;60:1577-85.

9. Pitocco D, Fuso L, Conte EG, Zaccardi F, Condoluci C, Scavone $\mathrm{G}$, et al. The diabetic lung-a new target organ? Rev Diabet Stud. 2012;9:23-35.

10. Lange P, Groth S, Kastrup J, Mortensen J, Appleyard M, Nyboe J, et al. Diabetes mellitus, plasma glucose and lung function in a cross-sectional population study. Eur Respir J. 1989;2:14-9.

11. Singh S, Prakash YS, Linneberg A, Agrawal A. Insulin and the lung: connecting asthma and metabolic syndrome. J Allergy (Cairo). 2013;2013:627384.

12. Bottini P, Scionti L, Santeusanio F, Casucci G, Tantucci C. Impairment of the respiratory system in diabetic autonomic neuropathy. Diabetes Nutr Metab. 2000;13:165-72.

13. Forgiarini LA Jr, Kretzmann NA, Porawski M, Dias AS, Marroni NA. Experimental diabetes mellitus: oxida oxidative stress and changes in lung structure. J Bras Pneumol. 2009;35:788-91. 
14. Hsia CC, Raskin P. The diabetic lung: relevance of alveolar microangiopathy for the use of inhaled insulin. Am J Med. 2005;118: 205-11.

15. Kuziemski K, Specjalski K, Jassem E. Diabetic pulmonary microangiopathy - fact or fiction? Endokrynol Pol. 2011;62:171-6.

16. Soulis T, Thallas V, Youssef S, Gilbert RE, McWilliam BG, Murray-McIntosh RP, et al. Advanced glycation end products and their receptors co-localise in rat organs susceptible to diabetic microvascular injury. Diabetologia. 1997;40:619-28.

17. Soulis T, Cooper ME, Sastra S, Thallas V, Panagiotopoulos S, Bjerrum OJ, et al. Relative contributions of advanced glycation and nitric oxide synthase inhibition to aminoguanidine-mediated renoprotection in diabetic rats. Diabetologia. 1997;40:1141-51.

18. Hamlin CR, Kohn RR, Luschin JH. Apparent accelerated aging of human collagen in diabetes mellitus. Diabetes. 1975;24:902-4.

19. Cavan DA, Parkes A, O'Donnell MJ, Freeman W, Cayton RM. Lung function and diabetes. Respir Med. 1991;85:257-8.

20. Ofulue AF, Thurlbeck WM. Experimental diabetes and the lung. II. In vivo connective tissue metabolism. Am Rev Respir Dis. 1988;138:284-9.

21. Kida K, Fujino Y. Lung structure and elastic recoil properties in hereditary diabetes mellitus in KK-mice, C57 black mice, and F1 hybrids. J Lab Clin Med. 1993;122:524-32.

22. Foster DJ, Ravikumar P, Bellotto DJ, Unger RH, Hsia CC. Fatty diabetic lung: altered alveolar structure and surfactant protein expression. Am J Physiol Lung Cell Mol Physiol. 2010;298:392403.

23. Treviño-Alanís M, Ventura-Juárez J, Hernández-Piñero J, Nevárez-Garza A, Quintanar-Stephano A, González-Piña A. Delayed lung maturation of foetus of diabetic mother rats develop with a diminish, but without changes in the proportion of type I and II pneumocytes, and decreased expression of protein Dassociated surfactant factor, Anat. Histol. Embryol. 2009;38: 169-76.

24. Heimer D, Brami J, Lieberman D, Bark H. Respiratory muscle performance in patients with type 1 diabetes. Diabet Med. 1990;7: 434-7.

25. Fuso L, Pitocco D, Longobardi A, Zaccardi F, Contu C, Pozzuto $\mathrm{C}$, et al. Reduced respiratory muscle strength and endurance in type 2 diabetes mellitus. Diabetes Metab Res Rev. 2012;28:370-5.

26. Schuyler MR, Niewoehner DE, Inkley SR, Kohn R. Abnormal lung elasticity in juvenile diabetes mellitus. Am Rev Respir Dis. 1976;113:37-41.

27. Davis WA, Knuiman M, Kendall P, Grange V, Davis TM. Glycemic exposure is associated with reduced pulmonary function in type 2 diabetes: the Fremantle diabetes study. Diabetes Care. 2004;27:752-7.

28. Lange P, Groth S, Mortensen J, Appleyard M, Nyboe J, Schnohr P, et al. Diabetes mellitus and ventilatory capacity: a five year follow-up study. Eur Respir J. 1990;3:288-92.

29. Antonelli Incalzi R, Fuso L, Pitocco D, Basso S, Trove A, Longobardi A, et al. Decline of neuroadrenergic bronchial innervation and respiratory function in type 1 diabetes mellitus: a longitudinal study. Diabetes Metab Res Rev. 2007;23:311-6.

30. Weiss SR, Cheng SL, Kourides IA, Gelfand RA, Landschulz WH. Inhaled insulin provides improved glycemic control in patients with type 2 diabetes mellitus inadequately controlled with oral agents: a randomized controlled trial. Arch Intern Med. 2003; 163:2277-82.

31. Skyler JS, Weinstock RS, Raskin P, Yale JF, Barrett E, Gerich JE, et al. Use of inhaled insulin in a basal/bolus insulin regimen in type 1 diabetic subjects: a 6-month, randomized, comparative trial. Diabetes Care. 2005;28:1630-5.

32. McKeever TM, Weston PJ, Hubbard R, Fogarty A. Lung function and glucose metabolism: an analysis of data from the third
National Health and nutrition examination survey. Am J Epidemiol. 2005; 161:546-56.

33. Lawlor DA, Ebrahim S, Smith GD. Associations of measures of lung function with insulin resistance and type 2 diabetes: findings from the British Women's heart and health study. Diabetologia. 2004;47:195-203.

34. Yeh HC, Punjabi NM, Wang NY, Pankow JS, Duncan BB, Cox $\mathrm{CE}$, et al. Crosssectional and prospective study of lung function in adults with type 2 diabetes: the atherosclerosis risk in communities (ARIC) study. Diabetes Care. 2008;31:741-6.

35. Guvener N, Tutuncu BN, Akcay S, Eyuboglu F, Gokcel A. Alveolar gas exchange in patients with type 2 diabetes mellitus. Endocr J. 2003;50:663-7.

36. Klein OL, Kalhan R, Williams MV, Tipping M, Lee J, Peng J, et al. Lung spirometry parameters and diffusion capacity are decreased in patients with type 2 diabetes. Diabet Med. 2012;29: 212-9.

37. Ozsahin K, Tugrul A, Mert S, Yüksel M, Tugrul G. Evaluation of pulmonary alveolo-capillary permeability in type 2 diabetes mellitus: using technetium 99mTc-DTPA aerosol scintigraphy and carbon monoxide diffusion capacity. J Diabetes Complicat. 2006;20:205-9.

38. Wheatley CM, Baldi JC, Cassuto NA, Foxx-Lupo WT, Snyder EM. Glycemic control influences lung membrane diffusion and oxygen saturation in exercise-trained subjects with type 1 diabetes: alveolar-capillary membrane conductance in type 1 diabetes. Eur J Appl Physiol. 2011;111:567-78.

39. Pitocco D, Santangeli P, Fuso L, Zaccardi F, Longobardi A, Infusino F, et al. Association between reduced pulmonary diffusing capacity and cardiac autonomic dysfunction in type 1 diabetes. Diabet Med. 2008;25:1366-9.

40. Nishimura M, Miyamoto K, Suzuki A, Yamamoto H, Tsuji M, Kishi F, et al. Ventilatory and heart responses to hypoxia and hypercapnia in patients with diabetes mellitus. Thorax. 1989;44: 251-7.

41. Weisbrod CJ, Eastwood PR, O’Driscoll GO, Green DJ. Abnormal ventilatory responses to hypoxia in type 2 diabetes. Diabet Med. 2005;22:563-8.

42. Antonelli Incalzi R, Fuso L, Giordano A, Pitocco D, Maiolo C, Calcagni ML, et al. Neuroadrenergic denervation of the lung in type I diabetes mellitus complicated by autonomic neuropathy. Chest. 2002;121:443-51.

43. Santos e Fonseca CM, Manco JC, Gallo Junior L, Barreira AA, Foss MC. Cholinergic bronchomotor tone and airway caliber in insulin-dependent diabetes mellitus. Chest. 1992;101:1038-43.

44. Koziel H, Koziel MJ. Pulmonary complications of diabetes mellitus. Pneumonia Infect Dis Clin North Am. 1995;9:65-96.

45. Vojtková J, Ciljaková M, Michnová Z, Turčan T. Chronic complications of diabetes mellitus related to the respiratory system. Pediatr Endocrinol Diabetes Metab. 2012;18:112-5.

46. Scano G, Seghieri G, Mancini M, Filippelli M, Duranti R, Fabbri A, et al. Dyspnoea, peripheral airway involvement and respiratory muscle effort in patients with type I diabetes mellitus under good metabolic control. Clin Sci (Lond). 1999;96:499-506.

47. Wanke T, Formanek D, Auinger M, Popp W, Zwick H, Irsigler K. Inspiratory muscle performance and pulmonary function changes in insulin-dependent diabetes mellitus. Am Rev Respir Dis. 1991;143:97-100.

48. Villa MP, Cacciari E, Bernardi F, Cicognani A, Salardi S, Zapulla F. Bronchial reactivity in diabetic patients. Relationship to duration of diabetes and degree of glycemic control. Am J Dis Child. 1988;142:726-9.

49. Wanke TH, Formanek D, Auginer M, Zwick H, Irsigler K. Pulmonary gas exchange and oxygen uptake during exercise in patients with type 1 diabetes mellitus. Diabet Med. 1992;9:252-7. 
50. Brassard P, Ferland A, Bogaty P, Desmeules M, Jobin J, Poirier P. Influence of glycemic control on pulmonary function and heart rate in response to exercise in subjects with type 2 diabetes mellitus. Metabolism. 2006;55:1532-7.

51. Ardigo D, Valtuena S, Zavaroni I, Baroni MC, Delsignore R. Pulmonary complications of diabetes mellitus: the role of glycemic control. Curr Drug Targets Inflamm Allergy. 2004;3:455-8.

52. Wolff SP, Dean RT. Glucose autoxidation and protein modification; potential role of autoxidative glycosylation in diabetes. Biochem J. 1987;245:243-50.

53. Goldman MD. Lung dysfunction in diabetes. Diabetes Care. 2003;26:1915-8.

54. Hsia CC, Raskin P. Lung function changes related to diabetes mellitus. Diabetes Technol Ther. 2007;9:73-82.

55. Hu FB, Manson JE, Liu S, Hunter D, Colditz GA, Michels KB, et al. Prospective study of adult onset diabetes mellitus (type 2) and risk of colorectal cancer in women. J Natl Cancer Inst. 1999;91:542-7.

56. Weiderpass E, Gridley G, Persson I, Nyren O, Ekbom A, Adami HO. Risk of endometrial and breast cancer in patients with diabetes mellitus. Int J Cancer. 1997;71:360-3.

57. Larsson SC, Wolk A. Diabetes mellitus and incidence of kidney cancer: a meta-analysis of cohort studies. Diabetologia. 2011;54: 1013-8.

58. Chow WH, Gridley G, Nyren O, Linet MS, Ekbom A, Fraumeni JF Jr, et al. Risk of pancreatic cancer following diabetes mellitus: a nationwide cohort study in Sweden. J Natl Cancer Inst. 1995;87: 930-1.

59. Argiles JM, Lopez-Soriano FJ. Insulin and cancer (review). Int J Oncol. 2001;18:683-7.

60. Kim WY, Jin Q, Oh SH, Kim ES, Yang YJ, Lee DH, et al. Elevated epithelial insulin-like growth factor expression is a risk factor for lung cancer development. Cancer Res. 2009;69:743948 .

61. Giovannucci E, Harlan DM, Archer MC, Bergenstal RM, Gapstur SM, Habel LA, et al. Diabetes and cancer: a consensus report. Diabetes Care. 2010;33:1674-85.

62. Ruano-Ravina A, Figueiras A, Barros-Dios JM. Lung cancer and related risk factors: an update of the literature. Public Health. 2003;117:149-56.

63. Strickler HD, Wylie-Rosett J, Rohan T, Hoover DR, Smoller S, Burk RD, et al. The relation of type 2 diabetes and cancer. Diabetes Technol Ther. 2001;3:263-74.

64. Wakai K, Ito Y, Suzuki K, Tamakoshi A, Seki N, Ando M, et al. Serum insulin-like growth factors, insulin-like growth factorbinding protein-3, and risk of lung cancer death: a case-control study nested in the Japan collaborative cohort (JACC) study. Jpn J Cancer Res. 2002;93:1279-86.

65. Ehrlich SF, Quesenberry CP Jr, Van Den Eeden SK, Shan J, Ferrara A. Patients diagnosed with diabetes are at increased risk for asthma, chronic obstructive pulmonary disease, pulmonary fibrosis, and pneumonia but not lung cancer. Diabetes Care. 2010;33:55-60.

66. Hall GC, Roberts CM, Boulis M, Mo J, MacRae KD. Diabetes and the risk of lung cancer. Diabetes Care. 2005;28:590-4.

67. Lee JY, Jeon I, Lee JM, Yoon JM, Park SM. Diabetes mellitus as an independent risk factor for lung cancer: a meta-analysis of observational studies. Eur J Cancer. 2013;49:2411-23.

68. Dankner R, Boker LK, Boffetta P, Balicer RD, Murad H, Berlin A, et al. A historical cohort study on glycemic-control and cancer-risk among patients with diabetes. Cancer Epidemiol. 2018;57:104-9.

69. De Giorgio R, Barbara G, Cecconi A, Corinaldesi R, Mancini AM. Diabetes is associated with longer survival rates in patients with malignant tumors. Arch Intern Med. 2000;160:2217.
70. Hatlen P, Grønberg BH, Langhammer A, Carlsen SM, Amundsen T. Prolonged survival in patients with lung cancer with diabetes mellitus. J Thorac Oncol. 2011;6:1810-7.

71. Rao Kondapally Seshasai S, Kaptoge S, Thompson A, Di Angelantonio E, Gao P, Sarwar N, et al. Emerging risk factors collaboration. Diabetes mellitus, fasting glucose, and risk of cause-specific death. N Engl J Med. 2011;364:829-41.

72. Vasic L. Locally advanced non-small cell lung cancerpretreatment prognostic factors: disease stage, tumor histopathological characteristics, the patient-related factors. Arch Oncol. 2007;15:19-23.

73. Karlin NJ, Amin SB, Buras MR, Kosiorek HE, Verona PM, Cook CB. Patient outcomes from lung cancer and diabetes mellitus: a matched case-control study. Future Sci OA. 2017;4:FSO248.

74. Satoh H, Ishikawa H, Kurishima K, Ohtsuka M, Sekizawa K. Diabetes is not associated with longer survival in patients with lung cancer. Arch Intern Med. 2001;161:485.

75. Xu T, Li D, He Y, Zhang F, Qiao M, Chen Y. Prognostic value of metformin for non-small cell lung cancer patients with diabetes. World J Surg Oncol. 2018;16:60.

76. Tsai MJ, Yang CJ, Kung YT, Sheu CC, Shen YT, Chang PY, et al. Metformin decreases lung cancer risk in diabetic patients in a dose-dependent manner. Lung Cancer. 2014;86:137-43.

77. Lin JJ, Gallagher EJ, Sigel K, Mhango G, Galsky MD, Smith CB, et al. Survival of patients with stage IV lung cancer with diabetes treated with metformin. Am J Respir Crit Care Med. 2015;191: 448-54.

78. Ferrara A, Lewis JD, Quesenberry CP Jr, Peng T, Strom BL, Van Den Eeden SK, et al. Cohort study of pioglitazone and cancer incidence in patients with diabetes. Diabetes Care. 2011;34:9239.

79. Smiechowski BB, Azoulay L, Yin H, Pollak MN, Suissa S. The use of metformin and the incidence of lung cancer in patients with type 2 diabetes. Diabetes Care. 2013;36:124-9.

80. Nie SP, Chen H, Zhuang MQ, Lu M. Anti-diabetic medications do not influence risk of lung cancer in patients with diabetes mellitus: a systematic review and meta-analysis. Asian Pac J Cancer Prev. 2014;15:6863-9.

81. Valerius N, Eff C, Hansen NE, Karle H, Nerup J, Søeberg B, et al. Neutrophil and lymphocyte function in patients with diabetes mellitus. Acta Med Scand. 1982;211:463-72.

82. Bhargava $\mathrm{P}$, Lee $\mathrm{CH}$. Role and function of macrophages in the metabolic syndrome. Biochem J. 2012;442:253-62.

83. Muller LM, Gorter KJ, Hak E, Goudzwaard WL, Schellevis FG, Hoepelman AI, et al. Increased risk of common infections in patients with type 1 and type 2 diabetes mellitus. Clin Infect Dis. 2005;41:281-8.

84. Peleg AY, Weerarathna T, McCarthy JS, Davis TM. Common infections in diabetes: pathogenesis, management and relationship to glycaemic control. Diabetes Metab Res Rev. 2007;23:3-13.

85. Fernández-Real JM, Valdés S, Manco M, Chico B, Botas $\mathrm{P}$, Campo A, et al. Surfactant protein d, a marker of lung innate immunity, is positively associated with insulin sensitivity. Diabetes Care. 2010;33:847-53.

86. Baker EH, Baines DL. Airway glucose homeostasis: a new target in the prevention and treatment of pulmonary infection. Chest. 2018;153:507-14.

87. Nirmal J, Caputo GM, Weitekamp MR, Karchmer AW. Infections in patients with diabetes mellitus. N Engl J Med. 1999;341:190612.

88. Higa M. Clinical epidemiology of fungal infection in diabetes. Nihon Rinsho. 2008;66:2239-44.

89. Diepersloot RJ, Bouter KP, Beyer WE, Hoekstra JB, Masurel N. Humoral immune response and delayed type hypersensitivity to influenza vaccine in patients with diabetes mellitus. Diabetologia. 1987;30:397-401. 
90. Kornum JB, Thomsen RW, Riis A, Lervang HH, Schønheyder HC, Sørensen HT. Diabetes, glycemic control, and risk of hospitalization with pneumonia: a population- based case-control study. Diabetes Care. 2008;31:1541-5.

91. Falguera M, Pifarre R, Martin A, Sheikh A, Moreno A. Etiology and outcome of community-acquired pneumonia in patients with diabetes mellitus. Chest. 2005;128:3233-9.

92. Bader MS, Abouchehade KA, Yi Y, Haroon B, Bishop LD, Hawboldt J. Antibiotic administration longer than eight hours after triage and mortality of community-acquired pneumonia in patients with diabetes mellitus. Eur J Clin Microbiol Infect Dis. 2011;30:881-6.

93. van de Garde EM, Hak E, Souverein PC, Hoes AW, van den Bosch JM, Leufkens HG. Statin treatment and reduced risk of pneumonia in patients with diabetes. Thorax. 2006;61:957-61.

94. van de Garde EM, Souverein PC, Hak E, Deneer VH, van den Bosch JM, Leufkens HG. Angiotensin-converting enzyme inhibitor use and protection against pneumonia in patients with diabetes. J Hypertens. 2007;25:235-9.

95. Seminog OO, Goldacre MJ. Risk of pneumonia and pneumococcal disease in people hospitalized with diabetes mellitus: English record-linkage studies. Diabet Med. 2013;30:1412-9.

96. Harries AD, Lin Y, Satyanarayana S, Lönnroth K, Li L, Wilson N, et al. The looming epidemic of diabetes-associated tuberculosis: learning lessons from the HIV-associated tuberculosis. Inter J Tuberc Lung Dis. 2011;15:1436-45.

97. Jeon CY, Murray MB. Diabetes mellitus increases the risk of active tuberculosis: a systematic review of 13 observational studies. PLoS Med. 2008;5:e152.

98. Restrepo BI, Schlesinger LS. Host-pathogen interactions in tuberculosis patients with type 2 diabetes mellitus. Tuberculosis. 2013;93:10-4.

99. Singla R, Khan N, Al Sharif N, Ai-Sayegh MO, Shaikh MA, Osman MM. Influence of diabetes on manifestations and treatment outcome of pulmonary TB patients. Int J Tuberc Lung Dis. 2006;10:74-9.

100. Restrepo BI, Fisher-Hoch SP, Crespo JG, Whitney E, Perez A, Smith B, et al. Nuevo Santander tuberculosis trackers. Crosssectional assessment reveals high diabetes prevalence among newly-diagnosed tuberculosis cases. Bull World Health Organ. 2011;89:352-9.

101. Dooley KE, Chaisson RE. Tuberculosis and diabetes mellitus: convergence of two epidemics. Lancet Infect Dis. 2009;9:737-46.

102. Baker MA, Harries AD, Jeon CY, Hart JE, Kapur A, Lönnroth K, et al. The impact of diabetes on tuberculosis treatment outcomes: a systematic review. BMC Med. 2011;9:81.

103. Delgado-Sánchez G, García-García L, Castellanos-Joya M, CruzHervert P, Ferreyra-Reyes L, Ferreira-Guerrero E, et al. Association of Pulmonary Tuberculosis and Diabetes in Mexico: analysis of the National Tuberculosis Registry 2000-2012. PLoS One. 2015;10:e129312.

104. Guirado E, Schlesinger LS, Kaplan G. Macrophages in tuberculosis: friend or foe. Semin Immunopathol. 2013;35:563-83.

105. Repasy T, Lee J, Marino S, Martinez N, Kirschner DE, Hendricks $\mathrm{G}$, et al. Intracellular bacillary burden reflects a burst size for Mycobacterium tuberculosis In vivo. PLoS Pathog. 2013;9: e1003190.

106. Gomez DI, Twahirwa M, Schlesinger LS, Restrepo BI. Reduced Mycobacterium tuberculosis association with monocytes from diabetes patients that have poor glucose control. Tuberculosis. 2013;93:192-7.

107. Restrepo BI, Twahirwa M, Rahbar MH, Schlesinger LS. Phagocytosis via complement or fc-gamma receptors is compromised in monocytes from type 2 diabetes patients with chronic hyperglycemia. PLoS One. 2014;26(9):e92977.
108. Musilli C, Paccosi S, Pala L, Gerlini G, Ledda F, Mugelli A, et al. Characterization of circulating and monocyte-derived dendritic cells in obese and diabetic patients. Mol Immunol. 2011;49:234 8 .

109. Zhang Q, Xiao HP, Cui HY, Sugawara I. Significant increase in natural-killer $\mathrm{T}$ cells in patients with tuberculosis complicated by type 2 diabetes mellitus. J Int Med Res. 2011;39:105-11.

110. Al-Attiyah RJ, Mustafa AS. Mycobacterial antigen-induced T helper type 1 (Th1) and Th2 reactivity of peripheral blood mononuclear cells from diabetic and non-diabetic tuberculosis patients and Mycobacterium bovis bacilli Calmette-Gue' rin (BCG)-vaccinated healthy subjects. Clin Exp Immunol. 2009;158:64-73.

111. Stalenhoef JE, Alisjahbana B, Nelwan EJ, van der Ven-Jongekrijg $\mathrm{J}$, Ottenhoff TH, van der Meer JW, et al. The role of interferon-g in the increased tuberculosis risk in type 2 diabetes mellitus. Eur J Clin Microbiol Infect Dis. 2008;27:97-103.

112. Restrepo BI, Fisher-Hoch SP, Pino PA, Salinas A, Rahbar MH, Mora F, et al. Tuberculosis in poorly controlled type 2 diabetes: altered cytokine expression in peripheral white blood cells. Clin Infect Dis. 2008;47:634-41.

113. Kumar NP, Sridhar R, Banurekha VV, Jawahar MS, Nutman TB, Babu S. Expansion of pathogen-specific Th1 and Th17 cells in pulmonary tuberculosis with coincident type 2 diabetes mellitus. J Infect Dis. 2013;208:739-48.

114. Kumar NP, Sridhar R, Banurekha VV, Jawahar MS, Fay MP, Nutman TB, et al. Type 2 diabetes mellitus coincident with pulmonary tuberculosis is associated with heightened systemic type 1, type 17 and other proinflammatory cytokines. Ann Am Thorac Soc. 2013;10:441-9.

115. Kumar NP, Sridhar R, Nair D, Banurekha VV, Nutman TB, Babu $\mathrm{S}$. Type 2 diabetes mellitus is associated with altered CD8(+) T and natural killer cell function in pulmonary tuberculosis. Immunology. 2015;144:677-86.

116. Blackman SM, Hsu S, Vanscoy LL, Collaco JM, Ritter SE, Naughton K, et al. Genetic modifiers play a substantial role in diabetes complicating cystic fibrosis. J Clin Endocrinol Metab. 2009;94:1302-9.

117. Lewis C, Blackman SM, Nelson A, Oberdorfer E, Wells D, Dunitz $\mathrm{J}$, et al. Diabetes-related mortality in adults with cystic fibrosis. Role of genotype and sex. Am J Respir Crit Care Med. 2015;191: 194-200.

118. van den Berg JM, Morton AM, Kok SW, Pijl H, Conway SP, Heijerman HG. Microvascular complications in patients with cystic fibrosis-related diabetes (CFRD). J Cyst Fibros. 2008;7:515-9.

119. Rosenecker J, Höfler R, Steinkamp G, Eichler I, Smaczny C, Ballmann M, et al. Diabetes mellitus in patients with cystic fibrosis: the impact of diabetes mellitus on pulmonary function and clinical outcome. Eur J Med Res. 2001;6:345-50.

120. Koch C, Rainisio M, Madessani U, Harms HK, Hodson ME, Mastella G, et al. Investigators of the European epidemiologic registry of cystic fibrosis. Presence of cystic fibrosis-related diabetes mellitus is tightly linked to poor lung function in patients with cystic fibrosis: data from the European epidemiologic registry of cystic fibrosis. Pediatr Pulmonol. 2001;32:343-50.

121. Milla CE, Warwick WJ, Moran A. Trends in pulmonary function in patients with cystic fibrosis correlate with the degree of glucose intolerance at baseline. Am J Respir Crit Care Med. 2000;162: 891-5.

122. Lanng S, Thorsteinsson B, Nerup J, Koch C. Influence of the development of diabetes mellitus on clinical status in patients with cystic fibrosis. Eur J Pediatr. 1992;151:684-7.

123. Rolon MA, Benali K, Munck A, Navarro J, Clement A, TubianaRufi N, et al. Cystic fibrosis-related diabetes mellitus: clinical impact of prediabetes and effects of insulin therapy. Acta Paediatr. 2001;90:860-7. 
124. Hameed S, Morton JR, Field PI, Belessis Y, Yoong T, Katz T, et al. Once daily insulin detemir in cystic fibrosis with insulin deficiency. Arch Dis Child. 2012;97:464-7.

125. Mozzillo E, Franzese A, Valerio G, Sepe A, De Simone I, Mazzarella G, et al. One-year glargine treatment can improve the course of lung disease in children and adolescents with cystic fibrosis and early glucose derangements. Pediatr Diabetes. 2009;10:162-7.

126. Nousia-Arvanitakis S, Galli-Tsinopoulou A, Karamouzis M. Insulin improves clinical status of patients with cystic-fibrosisrelated diabetes mellitus. Acta Paediatr. 2001;90:515-9.

127. Dobson L, Hattersley AT, Tiley S, Elworthy S, Oades PJ, Sheldon CD. Clinical improvement in cystic fibrosis with early insulin treatment. Arch Dis Child. 2002;87:430-1.

128. Limoli DH, Yang J, Khansaheb MK, Helfman B, Peng L, Stecenko AA, et al. Staphylococcus aureus and Pseudomonas aeruginosa co-infection is associated with cystic fibrosis-related diabetes and poor clinical outcomes. Eur J Clin Microbiol Infect Dis. 2016;35:947-53.

129. Fahy JV. Type 2 inflammation in asthma — present in most, absent in many. Nat Rev Immunol. 2015;15:57-65.

130. Douek IF, Leech NJ, Gillmor HA, Bingley PJ, Gale EA. Children with type 1 diabetes and their unaffected siblings have fewer symptoms of asthma. Lancet. 1999;353:1850.

131. Dahlquist G, Patterson C, Soltesz G. Decreased prevalence of atopic diseases in children with diabetes. The EURODIAB substudy 2 study group. J Pediatr. 2000;137:470-4.

132. Meerwaldt R, Odink RJ, Landaeta R, Aarts F, Brunekreef B, Gerritsen J, et al. A lower prevalence of atopy symptoms in children with type 1 diabetes mellitus. Clin Exp Allergy. 2002;32: 254-5.

133. Cardwell CR, Shields MD, Carson DJ, Patterson CC. A metaanalysis of the association between childhood type 1 diabetes and atopic disease. Diabetes Care. 2003;26:2568-74.

134. Metsälä J, Lundqvist A, Virta LJ, Kaila M, Gissler M, Virtanen SM, et al. The association between asthma and type 1 diabetes: a paediatric case-cohort study in Finland, years 1981-2009. Int J Epidemiol. 2018;47:409-16.

135. Stene LC, Nafstad P. Relation between occurrence of type 1 diabetes and asthma. Lancet. 2001;357:607-8.

136. Kero J, Gissler M, Hemminki E, Isolauri E. Could Th1 and Th2 diseases coexist? Evaluation of asthma incidence in children with coeliac disease, type 1 diabetes, or rheumatoid arthritis: a register study. J Allergy Clin Immunol. 2001;108:781-3.

137. Hsiao YT, Cheng WC, Liao WC, Lin CL, Shen TC, Chen WC, et al. Type 1 diabetes and increased risk of subsequent asthma: a Nationwide population-based cohort study. Medicine (Baltimore). 2015;94:e1466

138. Kondrashova A, Seiskari T, Ilonen J, Knip M, Hyöty H. The 'Hygiene hypothesis' and the sharp gradient in the incidence of autoimmune and allergic diseases between Russian Karelia and Finland. APMIS. 2013;121:478-93.

139. Black MH, Anderson A, Bell RA, Dabelea D, Pihoker C, Saydah $\mathrm{S}$, et al. Prevalence of asthma and its association with glycemic control among youth with diabetes. Pediatrics. 2011;128:839-47.

140. Rachmiel M, Bloch O, Bistritzer T, Weintrob N, Ofan R, KorenMorag N, et al. TH1/TH2 cytokine balance in patients with both type 1 diabetes mellitus and asthma. Cytokine. 2006;34:170-6.

141. Rachmiel M, Bloch O, Shaul AA, Ben-Yehudah G, Bistritzer Z, Weintrob N, et al. Young patients with both type 1 diabetes mellitus and asthma have a unique IL-12 and IL-18 secretory pattern. Pediatr Diabetes. 2011;12:596-603.

142. Kolahian S, Asadi F, Nassiri SM. Airway inflammatory events in diabetic-antigen sensitized Guinea pigs. Eur J Pharmacol. 2011;659:252-8.
143. Cavalher-Machado SC, de Lima WT, Damazo AS, de Frias Carvalho V, Martins MA, de Silva PM, Sannomiya P. Downregulation of mast cell activation and airway reactivity in diabetic rats: role of insulin. Eur Respir J 2004;24:552-558.

144. Szilvássy J, Sziklai I, Horvath P, Szilasi M, Németh J, Kovács P, et al. Feeble bronchomotor responses in diabetic rats in association with decreased sensory neuropeptide release. Am J Physiol Lung Cell Mol Physiol. 2002;282:1023-30.

145. Belmonte K, Jacoby D, Fryer A. Increased function of inhibitory neuronal M2 muscarinic receptors in diabetic rat lungs. Br J Pharmacol. 1997;121:1287-94.

146. Belmonte K, Fryer A, Costello R. Role of insulin in antigeninduced airway eosinophilia and neuronal M2 muscarinic receptor dysfunction. J Appl Physiol. 1998;85:1708-18.

147. Lee EJ, In KH, Ha ES, Lee KJ, Hur GY, Kang EH, et al. Asthmalike symptoms are increased in the metabolic syndrome. J Asthma. 2009;46:339-42.

148. Thuesen BH, Husemoen LL, Hersoug LG, Pisinger C, Linneberg A. Insulin resistance as a predictor of incident asthma-like symptoms in adults. Clin Exp Allergy. 2009;39:700-7.

149. Ma J, Xiao L, Knowles SB. Obesity, insulin resistance and the prevalence of atopy and asthma in US adults. Allergy. 2010;65: 1455-63.

150. Husemoen LL, Glümer C, Lau C, Pisinger C, Mørch LS, Linneberg A. Association of obesity and insulin resistance with asthma and aeroallergen sensitization. Allergy. 2008;63:575-82.

151. Movahed M, Hashemzadeh M, Jamal M. Increased prevalence of asthma in patients with type 2 diabetes mellitus. Chest. 2006;130: $160 \mathrm{~S}$.

152. Beuther DA, Sutherland ER. Overweight, obesity, and incident asthma: a metaanalysis of prospective epidemiologic studies. Am J Respir Crit Care Med. 2007;175:661-6.

153. Pradeepan S, Garrison G, Dixon AE. Obesity in asthma: approaches to treatment. Curr Allergy Asthma Rep. 2013;13:434 42.

154. Azad MB, Becker AB, Kozyrskyj AL. Association of maternal diabetes and child asthma. Pediatr Pulmonol. 2013;48(6):545-52.

155. Scholtens S, Wijga AH, Brunekreef B, Kerkhof M, Postma DS, Oldenwening $\mathrm{M}$, et al. Maternal overweight before pregnancy and asthma in offspring followed for 8 years. Int J Obes. 2010;34:60613.

156. Viardot A, Grey ST, Mackay F, Chisholm D. Potential antiinflammatory role of insulin via the preferential polarization of effector T cells toward a T helper 2 phenotype. Endocrinology. 2007;148:346-53.

157. Lessmann E, Grochowy G, Weingarten L, Giesemann T, Aktories $\mathrm{K}$, Leitges $\mathrm{M}$, et al. Insulin and insulin-like growth factor-1 promote mast cell survival via activation of the phosphatidylinositol3-kinase pathway. Exp Hematol. 2006;34:1532-41.

158. Noveral JP, Bhala A, Hintz RL, Grunstein MM, Cohen P. Insulinlike growth factor axis in airway smooth muscle cells. Am J Phys. 1994;267:761-5.

159. Gosens R, Nelemans SA, Hiemstra M, Grootte Bromhaar MM, Meurs H, Zaagsma J. Insulin induces a hypercontractile airway smooth muscle phenotype. Eur J Pharmacol. 2003;481:125-31.

160. Gosens R, Schaafsma D, Meurs H, Zaagsma J, Nelemans SA. Role of rho-kinase in maintaining airway smooth muscle contractile phenotype. Eur J Pharmacol. 2004;483:71-8.

161. Mirrakhimov AE. Chronic obstructive pulmonary disease and glucose metabolism: a bitter sweet symphony. Cardiovasc Diabetol. 2012:11:132.

162. Kinney GL, Black-Shinn JL, Wan ES, Make B, Regan E, Lutz S, et al. COPDGene investigators. Pulmonary function reduction in diabetes with and without chronic obstructive pulmonary disease. Diabetes Care. 2014;37:389-95. 
163. Mannino DM, Thorn D, Swensen A, Holguin F. Prevalence and outcomes of diabetes, hypertension and cardiovascular disease in COPD. Eur Respir J. 2008;32:962-9.

164. Miller J, Edwards LD, Agustí A, Bakke P, Calverley PM, Celli B, et al. Evaluation of COPD longitudinally to identify predictive surrogate endpoints (ECLIPSE) investigators. Comorbidity, systemic inflammation and outcomes in the ECLIPSE cohort. Respir Med. 2013;107:1376-84.

165. Baker EH, Janaway CH, Philips BJ, Brennan AL, Baines DL, Wood DM, et al. Hyperglycaemia is associated with poor outcomes in patients admitted to hospital with acute exacerbations of chronic obstructive pulmonary disease. Thorax. 2006;61:284 9.

166. Chakrabarti B, Angus RM, Agarwal S, Lane S, Calverley PM. Hyperglycaemia as a predictor of outcome during non-invasive ventilation in decompensated COPD. Thorax. 2009;64:857-62.

167. Mamillapalli C, Tentu R, Jain NK, Bhandari R. COPD and type 2 diabetes. Curr Respir Med Rev. 2019;15:1-8.

168. Cazzola M, Bettoncelli G, Sessa E, Cricelli C, Biscione G. Prevalence of comorbidities in patients with chronic obstructive pulmonary disease. Respiration. 2010;80:112-9.

169. Lee T, Mao IC, Lin CH, Lin SH, Hsieh MC. Chronic obstructive pulmonary disease: a risk factor for type 2 diabetes: a nationwide population-based study. Eur J Clin Investig. 2013;43:1113-9.

170. Lindberg A, Larsson LG, Rönmark E, Lundbäck B. Co-morbidity in mild-to-moderate COPD: comparison to normal and restrictive lung function. COPD. 2011;8:421-8.

171. Joo H, Park J, Lee SD, Oh YM. Comorbidities of chronic obstructive pulmonary disease in Koreans: a population-based study. J Korean Med Sci. 2012;27:901-6.

172. O'Byrne PM, Rennard S, Gerstein H, Radner F, Peterson S, Lindberg B, et al. Risk of new onset diabetes mellitus in patients with asthma or COPD taking inhaled corticosteroids. Respir Med. 2012;106:1487-93.

173. Habib G, Dar-Esaif Y, Bishara H, Artul S, Badarny S, Chernin M, et al. The impact of corticosteroid treatment on hemoglobin A1C levels among patients with type- 2 diabetes with chronic obstructive pulmonary disease exacerbation. Respir Med. 2014;108: 1641-6.

174. Bishwakarma R, Zhang W, Lin YL, Kuo YF, Cardenas VJ, Sharma G. Metformin use and health care utilization in patients with coexisting chronic obstructive pulmonary disease and diabetes mellitus. Int J Chron Obstruct Pulmon Dis. 2018;13:793-800.

175. Yen FS, Chen W, Wei JC, Hsu CC, Hwu CM. Effects of metformin use on total mortality in patients with type 2 diabetes and chronic obstructive pulmonary disease: a matched-subject design. PLoS One. 2018;13:e0204859.

176. Yu S, Christiani DC, Thompson BT, Bajwa EK, Gong MN. Role of diabetes in the development of acute respiratory distress syndrome. Crit Care Med. 2013;41:2720e2732.

177. Singla A, Turner P, Pendurthi MK, Agrawal V, Modrykamien A. Effect of type II diabetes mellitus on the outcomes in patients with acute respiratory distress syndrome. J Crit Care. 2014;29:66e69.

178. Boyle AJ, Madotto F, Laffey JG, Bellani G, Pham T, Pesenti A, et al. ESICM trials group. Identifying associations between diabetes and acute respiratory distress syndrome in patients with acute hypoxemic respiratory failure: an analysis of the LUNG SAFE database. Crit Care. 2018;22:268.

179. Esper A, Moss M. Diabetes and acute respiratory distress syndrome: can we finally believe the epidemiology? Crit Care Med. 2013;41:2822-3.

180. Kor DJ, Warner DO, Alsara A, Fernández-Pérez ER, Malinchoc M, Kashyap R, et al. Derivation and diagnostic accuracy of the surgical lung injury prediction model. Anesthesiology. 2011;115: $117-28$.
181. Koh GC, Vlaar AP, Hofstra JJ, de Jong HK, van Nierop S, Peacock SJ, et al. In the critically ill patient, diabetes predicts mortality independent of statin therapy but is not associated with acute lung injury: a cohort study. Crit Care Med. 2012;40:183543.

182. Moss M, Guidot DM, Steinberg KP, Duhon GF, Treece P, Wolken $\mathrm{R}$, et al. Diabetic patients have a decreased incidence of acute respiratory distress syndrome. Crit Care Med. 2000;28:2187-92.

183. Gong MN, Thompson BT, Williams P, Pothier L, Boyce PD, Christiani DC. Clinical predictors of and mortality in acute respiratory distress syndrome: potential role of red cell transfusion. Crit Care Med. 2005;33:1191-8

184. Iscimen R, Cartin-Ceba R, Yilmaz M, Khan H, Hubmayr RD, Afessa B, et al. Risk factors for the development of acute lung injury in patients with septic shock: An observational cohort study. Crit Care Med. 2008;36:1518-22.

185. Trillo-Alvarez C, Cartin-Ceba R, Kor DJ, Kojicic M, Kashyap R, Thakur S, et al. Acute lung injury prediction score: derivation and validation in a population-based sample. Eur Respir J. 2011;37: 604-9.

186. Dabbagh O, Park PK, Adesanya A, Chang SY, Hou P, Anderson H 3rd, et al. Early identification of patients at risk of acute lung injury: evaluation of lung injury prediction score in a multicenter cohort study. Am J Respir Crit Care Med. 2011;183:462-70.

187. Esper AM, Moss M, Martin GS. The effect of diabetes mellitus on organ dysfunction with sepsis: An epidemiological study. Crit Care. 2009;13:R18.

188. Alba-Loureiro TC, Munhoz CD, Martins JO, Cerchiaro GA, Scavone C, Curi R, et al. Neutrophil function and metabolism in individuals with diabetes mellitus. Braz J Med Biol Res. 2007;40: 1037-44.

189. Filgueiras LR Jr, Martins JO, Serezani CH, Capelozzi VL, Montes MB, Jancar S. Sepsis-induced acute lung injury (ALI) is milder in diabetic rats and correlates with impaired NFkB activation. PLoS One. 2012;7:e44987.

190. Ahamed K, Epaud R, Holzenberger M, Bonora M, Flejou JF, Puard J, et al. Deficiency in type 1 insulin-like growth factor receptor in mice protects against oxygen-induced lung injury. Respir Res. 2005;6:31.

191. Bellmeyer A, Martino JM, Chandel NS, Scott Budinger GR, Dean DA, Mutlu GM. Leptin resistance protects mice from hyperoxiainduced acute lung injury. Am J Respir Crit Care Med. 2007;175:587-94.

192. De Oliveira MJ, Meyer-Pflug AR, Alba-Loureiro TC, Melbostad H, Costa da Cruz JW, Coimbra R, et al. Modulation of lipopolysaccharide-induced acute lung inflammation: role of insulin. Shock. 2006;25:260-6.

193. Wright JK, Nwariaku FN, Clark J, Falck JC, Rogers T, Turnage $\mathrm{RH}$. Effect of diabetes mellitus on endotoxin-induced lung injury. Arch Surg. 1999;134:1354-9.

194. Alba-Loureiro TC, Martins EF, Landgraf RG, Jancar S, Curi R, Sannomiya P. Role of insulin on PGE2 generation during LPSinduced lung inflammation in rats. Life Sci. 2006;78:578-85.

195. Van den Berghe G, Wouters P, Weekers F, Verwaest C, Bruyninckx F, Schetz M, et al. Intensive insulin therapy in critically ill patients. N Engl J Med. 2001;345:1359-67.

196. Van den Berghe G, Wilmer A, Hermans G, Meersseman W, Wouters PJ, Milants I, et al. Intensive insulin therapy in the medical ICU. N Engl J Med. 2006;354:449-61.

197. Chen HI, Yeh DY, Liou HL, Kao SJ. Insulin attenuates endotoxininduced acute lung injury in conscious rats. Crit Care Med. 2006;34:758-64.

198. Filgueiras LR, Capelozzi VL, Martins JO, Jancar S. Sepsisinduced lung inflammation is modulated by insulin. BMC Pulm Med. 2014;14:177. 
199. Liu D, Zeng BX, Zhang SH, Wang YL, Zeng L, Geng ZL, et al. Rosiglitazone, a peroxisome proliferator-activated receptorgamma agonist, reduces acute lung injury in endotoxemic rats. Crit Care Med. 2005;33:2309-16.

200. Zmijewski JW, Lorne E, Zhao X, Tsuruta Y, Sha Y, Liu G, et al. Mitochondrial respiratory complex I regulates neutrophil activation and severity of lung injury. Am J Respir Crit Care Med. 2008;178:168-79.

201. Kawasaki T, Chen W, Htwe YM, Tatsumi K, Dudek SM. DPP4 inhibition by sitagliptin attenuates LPS-induced lung injury in mice. Am J Physiol Lung Cell Mol Physiol. 2018;315:834-45.

202. Wösten-van Asperen RM, Lutter R, Haitsma JJ, Merkus MP, van Woensel JB, van der Loos CM, et al. ACE mediates ventilatorinduced lung injury in rats via angiotensin II but not bradykinin. Eur Respir J. 2008;31:363-71.

203. Yao HW, Mao LG, Zhu JP. Protective effects of pravastatin in murine lipopolysaccharideinduced acute lung injury. Clin Exp Pharmacol Physiol. 2006;33:793-7.

204. Jacobson JR, Barnard JW, Grigoryev DN, Ma SF, Tuder RM, Garcia JG. Simvastatin attenuates vascular leak and inflammation in murine inflammatory lung injury. Am J Physiol Lung Cell Mol Physiol. 2005;288:1026-32.

205. Galiè N, Torbicki A, Barst R, Dartevelle P, Haworth S, Higenbottam T, et al. Guidelines on diagnosis and treatment of pulmonary arterial hypertension. The task force on diagnosis and treatment of pulmonary arterial hypertension of the European Society of Cardiology. Eur Heart J. 2004;25:2243-78.

206. Cooper ME, Bonnet F, Oldfield M, Jandeleit-Dahm K. Mechanisms of diabetic vasculopathy: an overview. Am J Hypertens. 2001;14:475-86.

207. Movahed MR, Hashemzadeh M, Jamal MM. The prevalence of pulmonary embolism and pulmonary hypertension in patients with type II diabetes mellitus. Chest. 2005;128:3568-71.

208. Poms AD, Turner M, Farber HW, Meltzer LA, McGoon MD. Comorbid conditions and outcomes in patients with pulmonary arterial hypertension: a REVEAL registry analysis. Chest. 2013;144:169-76.

209. Benson L, Brittain EL, Pugh ME, Austin ED, Fox K, Wheeler L, et al. Impact of diabetes on survival and right ventricular compensation in pulmonary arterial hypertension. Pulm Circ. 2014;4:3118 .

210. Abernethy AD, Stackhouse K, Hart S, Devendra G, Bashore TM, Dweik R, et al. Impact of diabetes in patients with pulmonary hypertension. Pulm Circ. 2015;5:117-23.

211. Lopez-Lopez JG, Moral-Sanz J, Frazziano G, Gomez-Villalobos MJ, Flores-Hernandez J, Monjaraz E, et al. Diabetes induces pulmonary artery endothelial dysfunction by NADPH oxidase induction. Am J Physiol Lung Cell Mol Physiol. 2008;295:727-32.

212. Russ RD, Tobin BW. Differential pulmonary vascular effects of streptozotocin diabetes in male and female rats. Proc Soc Exp Biol Med. 1998;217:74-80.

213. Pugh ME, Robbins IM, Rice TW, West J, Newman JH, Hemnes AR. Unrecognized glucose intolerance is common in pulmonary arterial hypertension. J Heart Lung Transplant. 2011;30:904-11.

214. Zamanian RT, Hansmann G, Snook S, Lilienfeld D, Rappaport $\mathrm{KM}$, Reaven GM, et al. Insulin resistance in pulmonary arterial hypertension. Eur Respir J. 2009;33:318-24.

215. Belly MJ, Tiede H, Morty RE, Schulz R, Voswinckel R, Tanislav $\mathrm{C}$, et al. HbA1c in pulmonary arterial hypertension: a marker of prognostic relevance? J Heart Lung Transplant. 2012;31:1109-14.

216. Van Marter LJ, Leviton A, Allred EN, Pagano M, Sullivan KF, Cohen A, et al. Persistent pulmonary hypertension of the newborn and smoking and aspirin and nonsteroidal antiinflammatory drug consumption during pregnancy. Pediatrics. 1996;97:658-63.

217. Grinnan D, Farr G, Fox A, Sweeney L. The role of hyperglycemia and insulin resistance in the development and progression of pulmonary arterial hypertension. J Diabetes Res. 2016;2016: 2481659.

218. Widya RL, van der Meer RW, Smit JW, Rijzewijk LJ, Diamant M, Bax JJ, et al. Right ventricular involvement in diabetic cardiomyopathy. Diabetes Care. 2013;36:457-62.

219. Di Paolo S, Gesualdo L, Ranieri E, Grandaliano G, Schena FP. High glucose concentration induces the overexpression of transforming growth factor-beta through the activation of a platelet-derived growth factor loop in human mesangial cells. Am J Pathol. 1996;149:2095-106.

220. Hua H, Goldberg HJ, Fantus IG, Whiteside CI. High glucoseenhanced mesangial cell extracellular signal-regulated protein kinase activation and alpha1(IV) collagen expression in response to endothelin-1: role of specific protein kinase C isozymes. Diabetes. 2001;50:2376-83.

221. Dewachter L, Dewachter C, Belhaj A, Lalande S, Rondelet B, Remmelink $\mathrm{M}$, et al. Insulin-like growth factor-1 contributes to the pulmonary artery smooth muscle cell proliferation in pulmonary arterial hypertension. Eur Respir J. 2014;44:P316.

222. Ameshima S, Golpon H, Cool CD, Chan D, Vandivier RW, Gardai $\mathrm{SJ}$, et al. Peroxisome proliferator-activated receptor gamma (PPARgamma) expression is decreased in pulmonary hypertension and affects endothelial cell growth. Circ Res. 2003;92: 1162-9.

223. Callaghan MJ, Ceradini DJ, Gurtner GC. Hyperglycemia-induced reactive oxygen species and impaired endothelial progenitor cell function. Antioxid Redox Signal. 2005;7:1476-82.

224. Kizub IV, Klymenko KI, Soloviev AI. Protein kinase C in enhanced vascular tone in diabetes mellitus. Int J Cardiol. 2014; 174:230-42.

225. Gribbin J, Hubbard R, Smith C. Role of diabetes mellitus and gastro-oesophageal reflux in the etiology of idiopathic pulmonary fibrosis. Respir Med. 2009;103:927-31.

226. Alakhras M, Decker PA, Nadrous HF, Collazo-Clavell M, Ryu JH. Body mass index and mortality in patients with idiopathic pulmonary fibrosis. Chest. 2007;131:1448-53.

227. Matsubara T, Hara F. The pulmonary function and histopathological studies of the lung in diabetes mellitus. Nippon Ika Daigaku Zasshi. 1991;58:528-36.

228. Farina J, Furio V, Fernandez-Acenero MJ, Muzas MA. Nodular fibrosis of the lung in diabetes mellitus. Virchows Arch. 1995;427: 61-3.

229. Vracko R, Thorning D, Huang TW. Basal lamina of alveolar epithelium and capillaries: quantitative changes with aging and in diabetes mellitus. Am Rev Respir Dis. 1979;120:973-83.

230. Weynand B, Jonckheere A, Frans A, Rahier J. Diabetes mellitus induces a thickening of the pulmonary basal lamina. Respiration. 1999;66:14-9.

231. Enomoto T, Usuki J, Azuma A, Nakagawa T, Kudoh S. Diabetes mellitus may increase risk for idiopathic pulmonary fibrosis. Chest. 2003;123:2007-11.

232. García-Sancho Figueroa MC, Carrillo G, Pérez-Padilla R, Fernández-Plata MR, Buendía-Roldán I, Vargas MH, et al. Risk factors for idiopathic pulmonary fibrosis in a Mexican population. A case-control study. Respir Med. 2010;104:305-9.

233. Hu Y, Ma Z, Guo Z, Zhao F, Wang Y, Cai L, et al. Type 1 diabetes mellitus is an independent risk factor for pulmonary fibrosis. Cell Biochem Biophys. 2014;70:1385-91.

234. Kim YJ, Park JW, Kyung SY, An CH, Lee SP, Chung MP, et al. Association of diabetes mellitus and metabolic syndrome with idiopathic pulmonary fibrosis. Tuberc Respir Dis. 2009;67:11320.

235. Kim YJ, Park JW, Kyung SY, Lee SP, Chung MP, Kim YH, et al. Clinical characteristics of idiopathic pulmonary fibrosis patients with diabetes mellitus: the national survey in Korea from 2003 to 2007. J Korean Med Sci. 2012;27:756-60. 
236. Hyldgaard C, Hilberg O, Bendstrup E. How does comorbidity influence survival in idiopathic pulmonary fibrosis? Respir Med. 2014;108:647-53.

237. Matsuse T, Ohga E, Teramoto S, Fukayama M, Nagai R, Horiuchi $\mathrm{S}$, et al. Immunohistochemical localisation of advanced glycation end products in pulmonary fibrosis. J Clin Pathol. 1998;51:515-9.

238. Ofulue AF, Kida K, Thurlbeck WM. Experimental diabetes and the lung. I. Changes in growth, morphometry, and biochemistry. Am Rev Respir Dis. 1988;137:162-6.

239. Usuki J, Enomoto T, Azuma A, Matsuda K, Aoyama A, Kudoh S. Influence of hyperglycemia to the severity of pulmonary fibrosis. Chest. 2001;120:71S.

240. Kida K, Utsuyama M, Takizawa T, Thurlbeck WM. Changes in lung morphologic features and elasticity caused by streptozotocininduced diabetes mellitus in growing rats. Am Rev Respir Dis. 1983;128:125-31.

241. Forgiarini LA Jr, Kretzmann NA, Porawski M, Dias AS, Marroni NA. Experimental diabetes mellitus: oxidative stress and changes in lung structure. J Bras Pneumol. 2009;35:788-91.

242. Gumieniczek A, Hopkala H, Wojtowicz Z, Wysocka M. Changes in antioxidant status of lung tissue in experimental diabetes in rabbits. Clin Biochem. 2002;35:147-9.

243. Kinalski M, Sledziewski A, Telejko B, Zarzycki W, Kinalska I. Lipid peroxidation and scavenging enzyme activity in streptozotocin- induced diabetes. Acta Diabetol. 2000;37:179-83.

244. Oztay F, Kandil A, Gurel E, Ustunova S, Kapucu A, Balci H, et al. The relationship between nitric oxide and leptin in the lung of rat with streptozotocin-induced diabetes. Cell Biochem Funct. 2008;26:162-71.

245. Zheng F, Lu W, Wu F, Li H, Hu X, Zhang F. Recombinant decorin ameliorates the pulmonary structure alterations by downregulating transforming growth factor-beta1/SMADS signaling in the diabetic rats. Endocr Res. 2010;35:35-49.

246. Kolahian S, Sadri H, Shahbazfar AA, Amani M, Mazadeh A, Mirani M. The effects of leucine, zinc, and chromium supplements on inflammatory events of the respiratory system in type 2 diabetic rats. PLoS One. 2015;10:e0133374.

247. Carlson EC, Audette JL, Veitenheimer NJ, Risan JA, Laturnus DI, Epstein PN. Ultrastructural morphometry of capillary basement membrane thickness in normal and transgenic diabetic mice. Anat Rec A Discov Mol Cell Evol Biol. 2003;271:332-41.

248. Oishi K, Ohkura N, Kasamatsu M, Fukushima N, Shirai H, Matsuda J, et al. Tissue-specific augmentation of circadian PAI1 expression in mice with streptozotocin-induced diabetes. Thromb Res. 2004;114:129-35.

249. Yang JL, Tan Y, Ma ZS, Miao LN, Zhao FL, Cai L. Lung fibrosis in experimental type 1 diabetic mouse model: role of oxidative stress and inflammation. Diabetes. 2010;59:A245.

250. Wang CM, Hsu CT, Niu HS, Chang CH, Cheng JT, Shieh JM. Lung damage induced by hyperglycemia in diabetic rats: the role of signal transducer and activator of transcription 3 (STAT3). J Diabetes Complicat. 2016;30:1426-33.

251. Yang J, Tan Y, Zhao F, Ma Z, Wang Y, Zheng S, et al. Angiotensin II plays a critical role in diabetic pulmonary fibrosis most likely via activation of NADPH oxidase-mediated nitrosative damage. Am J Physiol Endocrinol Metab. 2011;301:132-44.

252. Papinska AM, Soto M, Meeks CJ, Rodgers KE. Long-term administration of angiotensin (1-7) prevents heart and lung dysfunction in a mouse model of type 2 diabetes $(\mathrm{db} / \mathrm{db})$ by reducing oxidative stress, inflammation and pathological remodeling. Pharmacol Res. 2016;107:372-80.

253. Kroll MH, Afshar-Kharghan V. Platelets in pulmonary vascular physiology and pathology. Pulm Circ. 2012;2:291-308.

254. Jagadapillai R, Rane MJ, Lin X, Roberts AM, Hoyle GW, Cai L, Gozal E. Diabetic Microvascular Disease and Pulmonary Fibrosis: The Contribution of Platelets and Systemic Inflammation. Int $J$ Mol Sci. 2016;17.

255. Singh S, Bodas M, Bhatraju NK, Pattnaik B, Gheware A, Parameswaran PK, et al. Hyperinsulinemia adversely affects lung structure and function. Am J Physiol Lung Cell Mol Physiol. 2016;310:837-45.

256. Mexas AM, Hess RS, Hawkins EC, Martin LD. Pulmonary lesions in cats with diabetes mellitus. J Vet Intern Med. 2006;20:4751.

Publisher's note Springer Nature remains neutral with regard to jurisdictional claims in published maps and institutional affiliations. 